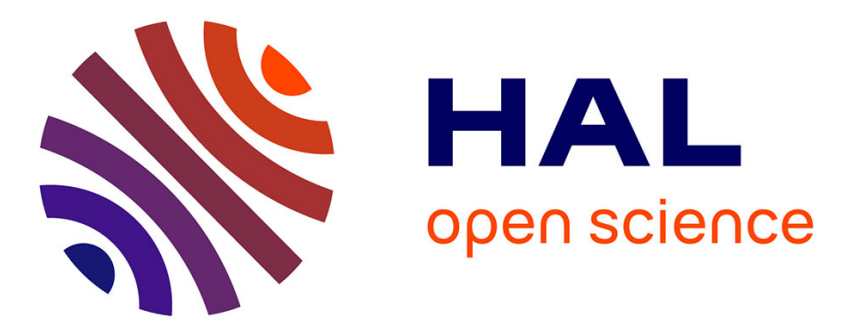

\title{
Seafloor litter sorting in different domains of Cap de Creus continental shelf and submarine canyon (NW Mediterranean Sea)
}

Carlos Dominguez-Carrió, Anna Sanchez-Vidal, Claude Estournel, Guillem Corbera, Joan Lluís Riera, Covadonga Orejas, Miquel Canals, Josep-Maria Gili

\section{To cite this version:}

Carlos Dominguez-Carrió, Anna Sanchez-Vidal, Claude Estournel, Guillem Corbera, Joan Lluís Riera, et al.. Seafloor litter sorting in different domains of Cap de Creus continental shelf and submarine canyon (NW Mediterranean Sea). Marine Pollution Bulletin, 2020. hal-03041748

\author{
HAL Id: hal-03041748 \\ https://cnrs.hal.science/hal-03041748
}

Submitted on 23 Dec 2021

HAL is a multi-disciplinary open access archive for the deposit and dissemination of scientific research documents, whether they are published or not. The documents may come from teaching and research institutions in France or abroad, or from public or private research centers.
L'archive ouverte pluridisciplinaire HAL, est destinée au dépôt et à la diffusion de documents scientifiques de niveau recherche, publiés ou non, émanant des établissements d'enseignement et de recherche français ou étrangers, des laboratoires publics ou privés. 


\section{Seafloor litter sorting in different domains of Cap de Creus continental shelf and submarine canyon (NW Mediterranean Sea)}

Carlos Dominguez-Carrióa ${ }^{a 1}$, Anna Sanchez-Vidal ${ }^{b}$, Claude Estournel ${ }^{\mathrm{c}}$, Guillem Corbera $^{\mathrm{a}}$, Joan Lluís Riera ${ }^{\mathrm{d}}$, Covadonga Orejas ${ }^{\mathrm{e}}$, Miquel Canals $^{\mathrm{b}}$, Josep-Maria Gili ${ }^{\mathrm{a}}$

${ }^{a}$ Institut de Ciències del Mar, Consejo Superior de Investigaciones Científicas, Passeig Marítim de la Barceloneta 37-49, 08003, Barcelona (Spain)

${ }^{b}$ GRC Geociències Marines, Departament de Dinàmica de la Terra i de l'Oceà, Universitat de Barcelona, Martí i Franquès s/n, 08028, Barcelona (Spain)

'Laboratoire d'Etudes en Géophysique et Océanographie Spatiales (LEGOS), CNRS/UPS/CNES/IRD, Avenue Edouard Belin 14, 31400, Toulouse (France)

${ }^{\mathrm{d} D e p a r t a m e n t}$ de Biologia Evolutiva, Ecologia i Ciències Ambientals, Universitat de Barcelona, Avinguda Diagonal 643, 08028, Barcelona (Spain)

${ }^{\text {e}}$ Centre Oceanogràfic de Balears, Instituto Español de Oceanografía, Moll de Ponent s/n 07015, Palma (Spain)

Corresponding author: Carlos Dominguez-Carrió (carlosdominguezcarrio@gmail.com)

${ }^{1}$ Present address: IMAR Instituto do Mar \& Okeanos Research Center, Departamento de Oceanografia e Pesca, Universidade dos Açores, Rua Prof. Doutor Frederico Machado 4, 9900-138, Horta (Portugal) 


\section{Abstract}

We analyzed litter occurrence in 68 underwater video transects performed on the middle/outer continental shelf and submarine canyon off Cap de Creus (NW Mediterranean), an area recently declared Site of Community Importance $(\mathrm{SCl})$. Low densities of urban litter were registered on the shelf (7.2 items ha ${ }^{-1}$ ), increasing in abundance towards the deepest part of the submarine canyon, with 188 items ha $^{-1}$ below $1000 \mathrm{~m}$ depth. We hypothesize that the strong bottom currents that recurrently affect this area efficiently move litter objects from the shelf towards the deep. Of all litter items, approximately $50 \%$ had a fishing-related origin, mostly longlines entangled on rocks in the canyon head and discarded trawl nets in deeper areas. Over $10 \%$ of coldwater colonies observed had longlines entangled, indicating the harmful effects of such practices over benthic habitats. These results should be considered when designing mitigation measures to reduce litter pollution in Cap de Creus SCI.

Keywords: plastics, funneling, litter hotspots, longlines, cold-water corals, continental margin

\section{Introduction}

The widespread distribution of materials produced by human societies that get stranded ashore or reach the seabed is now considered a critical issue in terms of marine conservation (Galgani et al., 2015, Rangel-Buitrago et al., 2020). Its presence in all parts of the ocean has alerted national and international authorities, researchers and stakeholders worldwide, which 
foresee the consequences of not properly addressing this issue in the forthcoming years (UNEP, 2009; Agamuthu et al., 2019). The vast majority of discarded items are primarily made of plastic or have plastic components (Jambeck et al., 2015; Beaumont et al., 2019), mainly due to its low manufacturing cost and its durability. This property also makes plastic extremely dangerous, since it can last for decades once discarded (Laist, 1987). After plastic items have reached the marine environment, measures to retrieve them are complex and expensive, especially with increasing depths (Iñiguez et al., 2016). Besides the aesthetic, health and economic problems derived from the accumulation of human-derived objects in the marine environment, litter is steadily becoming a serious threat to wildlife, since it can kill or harm all sorts of marine organisms, from algae to birds (Kühn et al., 2015). The list of deleterious effects caused over marine fauna is extensive, and includes among others the entanglement or smothering of sessile animals (Yoshikawa and Asoh, 2004) and the ingestion of fragmented litter by heterotrophic organisms (e.g. Courtene-Jones et al., 2018). Recent studies have documented the ingestion of microplastics by commercially important deep-sea species (Carreras-Colom et al., 2018; Cau et al., 2019), indicating the great implications that its accumulation may have for the marine ecosystem and also for human health.

In European seas, around $30 \%$ of all marine litter that accumulates on shelf, slope and canyon habitats can be attributed to abandoned, lost, or discarded fishing gear (ALDFG; Pham et al., 2014b), although this percentage can reach $50-80 \%$ in traditional fishing grounds, such as Campania, Sicily or Liguria (Angiolillo et al., 2015; Consoli et al., 2018; Enrichetti et al., 2020). These high 
percentages may be explained by the increase of the fishing effort during the past decades and a steady transition to synthetic and more durable materials to manufacture fishing nets and lines (Gilman et al., 2016), which lead to an increased likelihood of gear loss (Richardson et al., 2019). The remaining litter items observed over the seabed derive from a wide range of sources, yet most of them consist partially or entirely of plastic (Pham et al., 2014b; García-Rivera et al., 2018). It is now becoming very common to find plastic bottles, plastic bags and clothes half buried in the sediment or entangled around rocks in deep water environments (van den Beld et al., 2017; Moriarty et al., 2016). In the Mediterranean Sea, studies performed over the continental margin have found litter items in almost all surveyed sites (Angiolillo et al., 2015; Pasquini et al., 2016; García-Rivera et al., 2018; Gerigny et al., 2019; Enrichetti et al., 2020). Highest densities are generally registered in areas close to shore or immediately adjacent to large cities (Strafella et al., 2019; Buhl-Mortensen and Buhl-Mortensen, 2017), with accumulation areas ("litter hotspots") also observed at bathyal depths, either inside submarine canyons or following the path of the main oceanic currents (Tubau et al.; 2015; Cau et al., 2018; Pierdomenico et al., 2019).

Aiming to minimize the effects produced by human-derived objects in the marine environment, the European Commission included marine litter in the Marine Strategy Framework Directive (MSFD) as one of the 11 descriptors to be considered when assessing the achievement of 'Good Environmental Status' (GES) of European seas (Council of the European Union, 2008). The MSFD provides the legal framework to encourage Member States to report and subsequently monitor the abundance of marine litter in their territorial 
waters, leading to the implementation of area-specific management measures to reduce the amount of litter that reaches the marine environment, and designing specific actions to minimize land-based sources when possible (Galgani et al., 2013). The application of such measures, however, must be based upon a comprehensive knowledge of the actual composition, abundance and spatial distribution of marine litter in each area.

The continental shelf and the submarine canyon off Cap de Creus currently belong to a Site of Community Importance (SCI) of the Natura 2000 Network (BOE, 2014). Following the demands of the MSFD, the implementation of an ecosystem-based approach to manage human activities in Cap de Creus marine area requires a thorough evaluation of the amount of litter items that can be found in its shelf and canyon habitats. Making use of 68 underwater video dives performed between 80 and 1570 m depth prior to the declaration of the $\mathrm{SCl}$, this paper aims to (1) evaluate the quantity and spatial distribution of marine litter on the Cap de Creus continental shelf and submarine canyon, (2) identify the main causes of such distribution, and (3) assess the potential impacts of ALDFG over the three main cold-water coral species dwelling in the submarine canyon, namely Madrepora oculata, Lophelia pertusa and Dendrophyllia cornigera.

\section{Materials and methods}

\subsection{Study area}

The Gulf of Lion forms a prograding continental margin characterized by a rather wide continental shelf (up to $70 \mathrm{~km}$ ) and a complex network of submarine canyons incising its continental slope and shelf, which play a 
prominent role in the hydrological and sediment dynamics of the whole margin (Canals et al., 2004). The Rhône River supplies most of the terrigenous input to the gulf, with an average of more than $6.5 \mathrm{Mt}$ of suspended particulate matter discharged every year (Poulier et al., 2019). Most of the sediment remains stored on the shelf until specific atmospheric situations trigger highenergy oceanographic events such as dense shelf water cascading and sea storms that are able to resuspend and transport large quantities of sediment, organic matter and pollutants to the deep, mainly along submarine canyons (Canals et al., 2006; Palanques et al., 2006; Salvadó et al., 2012, 2017).

Cap de Creus Canyon is located at the southernmost end of the Gulf of Lion shelf. The canyon head is just $4 \mathrm{~km}$ ahead of Cap de Creus promontory and is deeply incised on the continental shelf at $125 \mathrm{~m}$ depth (Figure 1; Lastras et al., 2007). Because of its location at the southern exit of the dominant circulation pattern in the Gulf of Lion, and also because of the obstacle effect of the promontory that deviates offshore coastal and shelf currents, Cap de Creus Canyon behaves as the preferential conduit of water and sediment from the gulf's shelf to the deep margin and basin (Canals et al., 2006; Palanques et al., 2006). The presence of strong bottom currents and the supply of large quantities of organic material favors the development of rich benthic communities, both on the continental shelf and the submarine canyon (Dominguez-Carrió, 2018), where dense patches of cold-water corals, mainly Madrepora oculata, have been observed (Orejas et al., 2009).

Most of Cap de Creus peninsula was declared a maritime-terrestrial Natural Park in 1998, including a narrow shallow water peripheral belt of the innermost continental shelf (mostly infralittoral stage) (BOE, 1998). It was in 
2014 when a large part of the continental shelf and the submarine canyon was included in the Site of Community Importance "South-West Gulf of Lion canyons system", as part of the Natura 2000 Network of protected areas of the European Union (Area ESZZ16001; BOE, 2014).

\subsection{Video surveys and imagery analysis}

The extensive dataset used in this study was obtained from 68 underwater dives performed during 5 oceanographic cruises between 2007 and 2013, as part of the HERMES, DEEP CORAL, PROMARES and Life+ INDEMARES projects. Four different underwater vehicles were used: the manned submersible JAGO (GEOMAR, Germany), the commercial ROV Liropus 2000 (IEO, Spain), the purpose built ROV Nemo (Gavin Newman, UK) and the small and compact ROV Bleeper EVO (ICM-CSIC, Spain). All vehicles but Bleeper EVO were equipped with an HD camera and a USBL system to obtain accurate positions of the vehicle over the seabed, with a time frequency below 20 seconds. Bleeper EVO, which was only used on the continental shelf, had an SD definition camera and its position was inferred from that of the vessel and the angle of the cable when being towed over the seafloor. Geographic positioning data was used to calculate the distance travelled by the underwater vehicle in each dive. All platforms were equipped with parallel lasers to provide scale to the images. Metadata regarding each dive is provided in Table 1, with reference to the video platform used. Data obtained during the PROMARES cruise (dives 37 to 44 ) was partly published in Tubau et al. (2015), and considered in this study given its relevance to better determine spatial patterns in litter distribution along Cap de Creus submarine canyon. 
All underwater dives were performed from the mid and outer continental shelf (80-90 m water depth) down to the submarine canyon floor at $1600 \mathrm{~m}$ (Figure 1; Table 1). Dive length was extremely variable (from $80 \mathrm{~m}$ to $3 \mathrm{~km}$ ) and dependent on weather conditions, underwater visibility and bottom current speed. The total seafloor distance covered was $47.5 \mathrm{~km}$, which represents an area visually examined of about 7.5 ha. All transects were performed as straight as possible while keeping a constant speed above ground of $0.3 \mathrm{~m} \cdot \mathrm{s}^{-1}$ in average.

Final Cut Pro 7 (Apple Inc.) video editing software was used to remove the time intervals when the underwater vehicle stayed stationary, so multiple counting of the same item was avoided. Those sections with poor image quality, mostly due to sediment resuspension or excessive distance from the seabed, were also identified and subsequently removed from the statistical analyses. During the PROMARES cruise (dives 37-49), an average field of view (FOV) estimated at $3 \mathrm{~m}$ was selected for litter quantification (see details in Tubau et al., 2015). Dives performed with the manned submersible JAGO (dives 1-9 and 32-36) had an estimated average FOV of $2 \mathrm{~m}$. For the remaining transects, which were performed with smaller ROVs that filmed from a closer distance to the seabed, a $50 \mathrm{~cm}$ average FOV was chosen to calculate litter density. All human-derived items and cold-water coral colonies of the species Madrepora oculata, Lophelia pertusa (recently reclassified as Desmophyllum pertusum, see Addamo et al., 2016) and Dendrophyllia cornigera were identified and annotated within the selected field of view in each underwater dive.

\subsection{Data treatment}


Marine litter items were classified in two main categories: (1) ALDFG, which included bottom trawl nets, bottom trawl cables, longlines and trammel nets, and (2) urban litter, which was further subdivided in plastic, metal, glass, ceramics, clothing (regardless of its fabric), paper and wood. It should be noted that all fishing gears and related items, whether made of plastic or metal, were all attributed to ALDFG. Making use of transect length (L) and width $(\mathrm{W})$, densities for each litter category were calculated at the transect level as items per $\mathrm{ha}^{-1}$, simply dividing the number of items by the area explored in each dive $(\mathrm{De}=$ items $/ \mathrm{L} \cdot \mathrm{W})$.

To account for spatial and depth variability in the distribution of litter items, five domains were defined within the study area in and around Cap de Creus Canyon (Figure 1), following those defined by Lastras et al. (2007):

1. Northern mid and outer shelf (NS): the continental shelf north of the eastern tip of the cape, from 80 to $150 \mathrm{~m}$ depth.

2. Southern mid and outer shelf (SS): the continental shelf south of the eastern tip of the cape, also from 80 to 150 m depth

3. Canyon head $(\mathrm{CH})$ : from the shelf break at a mean depth of $150 \mathrm{~m}$ down to $400 \mathrm{~m}$ depth inside the canyon.

4. Upper canyon (UC): between 400 and 1000 m depth.

5. Middle canyon (MC): between 1000 and $1600 \mathrm{~m}$ depth.

The impact of ALDFG on the above-mentioned cold-water coral species was assessed by calculating the percentage of entangled colonies of each species along selected underwater dives (1-9) carried out in the canyon head, from 160 to 390 m depth.

\subsection{Modelling the bottom currents}


The free surface, generalized sigma vertical coordinate, 3D hydrodynamic model SYMPHONIE described by Marsaleix et al. $(2006,2008,2012)$ was used to calculate the bottom currents in the study area. This model classically solves the equations for temperature, salinity and the two components of horizontal current starting from initial conditions and using time-dependent forcing. The horizontal grid was designed to study the connections between the Gulf of Lions and the Catalan region with the south of the basin through the formation and dispersion of dense water. The resulting curvilinear grid had a pole positioned in the Pyrenees, allowing a minimum resolution of about 700 $\mathrm{m}$ near the French and Catalan coast, and increasing to reach $5-6 \mathrm{~km}$ near Algeria.

The model was initialized and forced at its open boundaries by the NEMOMED8 model described in Herrmann et al. (2010). At the surface, the same atmospheric forcing than this model was used i.e. the ARPERA dataset (Herrmann and Somot, 2008), which is a dynamic downscaling of the ERA40 climate model reanalysis (1976-2001) and of the ECMWF (European Centre for Medium-Range Weather Forecasts) model reanalysis since 2001. This forcing consists in daily averaged wind stress, solar flux, long wave net heat flux, sensible and latent heat flux and precipitation, leaving the diurnal cycle unresolved. The sea surface temperature was nudged towards the climatological one used in the NEMOMED8 model, ensuring the consistency between the two models. The two components of the horizontal current were then extracted from the daily outputs of the model, rotated to be along the WE and NS axis and interpolated on a regular grid. The simulations were run from the beginning of year 2000 to the end of 2013 , and the daily currents for the 
month of February 2012 were averaged to illustrate the strength of bottom currents in the area. This month was chosen because it is known to be an exceptional period of dense water formation on the Gulf of Lion shelf, with deep cascading in Cap de Creus Canyon (Durrieu de Madron et al., 2013; Sanchez-Vidal et al., 2015), a recurrent process known to occur periodically in the area. Although extreme deep-cascade events are not very frequent (highintensity events recorded in 1999, 2005 and 2012; e.g. Canals et al., 2006; Ulses et al., 2008; Durrieu de Madron et al., 2013), Mikolajczak et al. (2020) estimated that during the period 2010-2017, one year out of two, cascading could affect depths of $1000 \mathrm{~m}$, while in the remaining years it would only sporadically reach $500 \mathrm{~m}$ depth.

\section{Results}

\subsection{Composition of marine litter}

In total, 833 litter items were identified in the video images recorded on the continental shelf and submarine canyon off Cap de Creus. This corresponds to an average density of 110 items ha ${ }^{-1}$ for the entire study area $(80-1600 \mathrm{~m}$ depth). The number of items and density per dive, organized in the different litter categories, is provided in the Supplementary Table 1.

There were 394 urban litter items (47\% of the total), which appeared in $30 \%$ of the dives (Table 1). A wide variety of objects could be identified, including plastic and glass bottles, shopping bags, tin cans and clothes of different sorts (examples in Figure 2a-c). Very few items reached large sizes $(>1 \mathrm{~m})$ besides some car tires and an oil drum (Figure $2 \mathrm{~d}, \mathrm{e}$ ). The abundance of urban litter was generally low across dives, although density values exceeded 100 items 
ha $^{-1}$ in 4 transects (8-26-39-40). Plastic was the main component, with almost $80 \%$ of all urban litter objects completely made of plastic or included plastic parts. Six amphorae were also identified in the footage (Figure 2f).

About $53 \%$ of the total number of litter items (439) were classified as abandoned, lost or otherwise discarded fishing gears (ALDFG). The vast majority corresponded to longlines, with 371 items ( $85 \%$ of ALDFG; examples in Figure 2g,h). The number of bottom trawl nets and cables was much lower (56 items, 13\%; examples in Figure 2i,j), and trammel nets were the least common type of fishing gear, with only 12 items observed (3\% of all ALDFG; examples in Figure 2k,l).

\subsection{Spatial and depth distribution}

Mid and outer continental shelf. Urban litter items were not commonly observed on the videos registered on the continental shelf, with only 14 items annotated in 1.93 ha explored. This represents an average density of 7.2 items ha $^{-1}$ for the continental shelf, with recorded densities slightly higher on the northern side (Figure 3), although no clear pattern could be determined (Figure 4a). Plastic objects and objects with plastic components constituted around $38 \%$ of all reported urban litter ( 5 items), with densities below 4 items $h^{-1}$ on both shelves. Glass was the second most common category, with 4 items $(30 \%)$. Litter objects made of other materials, like metal $(8 \%)$, ceramics (15\%) and textiles (15\%), appeared in lower numbers, and no items made of wood and paper were reported. Densities of ALDFG were similar on both sides of the continental shelf (Figure 3), with slightly higher densities on the southern $\left(59.5\right.$ items $\left.^{-1}\right)$ than on the northern side $\left(45.6\right.$ items ha $\left.{ }^{-1}\right)$. Most 
ALDFG items were registered along the $100 \mathrm{~m}$ isobath north and east of the easternmost part of the cape (Figure 4b), where rocky outcrops and mixed substrates were generally observed in the images. Longlines were by far the most common type of ALDFG found on the continental shelf, accounting for $76 \%$ of all fishing-related items. With 79 longlines reported (NS: 33; SS: 46), densities on both sides stayed around 40 items ha- ${ }^{-1}$ (Figure 3). Trammel nets appeared only on the southern side ( $12 \%$ of ALDFG, 10.5 items ha ${ }^{-1}$ ), generally entangled over small and medium sized rocks (Figure 2k). Bottom trawl nets and cables represented $13 \%$ of all ALDFG, with most nets appearing on the southern shelf (NS: 3; SS: 10), where their density was around 8.7 items ha $^{-1}$ (Figure 3, examples in Figure 2i,j)

Canyon head. 28 urban litter items were identified on the 1.33 ha explored,

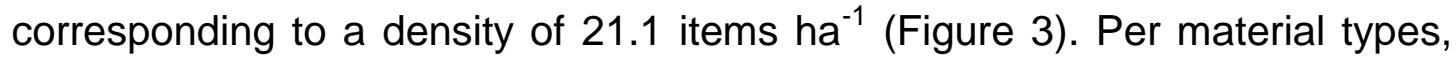
$51 \%$ of urban items were made of metal ( 11.3 items $^{-1}$ ) and $24 \%$ of plastic (5.3 items $\left.\mathrm{ha}^{-1}\right)$. The number of glass and clothing items was almost negligible. Most of the amphorae observed in the footage (4) were reported in the canyon head. ALDFG reached maximum values in this domain (323 items), with a density of 243.6 items ha ${ }^{-1}$ (Figure 3). All but 3 dives performed in the canyon head contained remains of ALDFG, with some dives reaching local densities above 500 items ha $^{-1}$, particularly on the westernmost part of the canyon head (Figure 4b). More than $80 \%$ of all ALDFG identified corresponded to longlines (290 items), which represents a density of 218.7 lines $\mathrm{ha}^{-1}$ (Figure 3 , examples in Figure $2 \mathrm{~g}, \mathrm{~h}$ ). It should be noted that according to the tradition in the area and the design of longlines and trammel nets, these two techniques are not practiced in areas deeper than $400 \mathrm{~m}$. 
Parts of bottom trawl nets also reached here the highest numbers of any domain (33 trawl nets and ropes, 24.9 items ha $^{-1}$ ), and were mostly observed as thick pulling ropes, especially in dive 42.

Upper canyon. Urban litter items were much more abundant in the upper canyon than in the previous two domains combined, with 122 items identified in the 3 ha explored, resulting in a density of 39.5 items ha ${ }^{-1}$ (Figure 3). Most objects were made or had plastic components $\left(76 \%, 30.1\right.$ items ha $\left.{ }^{-1}\right)$, with a smaller fraction made of metal items $\left(18 \%, 7.1\right.$ items ha $\left.^{-1}\right)$. Other materials were represented by objects made of wood, ceramics, glass and paper, all of them with densities lower than 1 item $\mathrm{ha}^{-1}$. The abundance of ALDFG decreased significantly below $400 \mathrm{~m}$ depth, with only 7 fishing-derived items identified in the upper canyon (2.3 items ha ${ }^{-1}$; Figure 3). All ALDFG in this depth range had a bottom-trawl origin, with most items being actual trawl nets (5) and pulling ropes (2) (Figure 5a).

Middle canyon. With 230 objects identified in the 1.2 ha explored, the highest number of urban litter items of any domain corresponded to the middle canyon (187.8 items ha ${ }^{-1}$; Figure 3 ). This represents $58.4 \%$ of urban litter items identified in the whole video footage. The largest fraction corresponded to items made of plastic, a material appearing in almost $90 \%$ of the urban items reported in this domain. In contrast, metal objects accounted for only $6 \%\left(11.4\right.$ items $\left.\mathrm{ha}^{-1}\right)$, whilst the remaining categories contributed with less than $1-3 \%$ each (Figure 3). In some specific areas at around $1200 \mathrm{~m}$ depth (Dive 40), there existed accumulations of several litter objects in a build-up appearance, forming what can be considered "litter hotspots", where some aged items were observed half buried under the sediment (example in Figure 
5b). Regarding ALDFG, 2 longlines and 3 bottom trawl nets were identified in the middle canyon, where an overall density of 4.1 items ha ${ }^{-1}$ was reported (Figure 3). It should be noted that bottom trawling is not usually practiced in Cap de Creus at depths below $800 \mathrm{~m}$.

\subsection{Bottom currents}

Bottom current speed and direction averaged for the month of February 2012 after applying a bilinear interpolation to the modelled data (gridded at $700 \times 700$ $\mathrm{m}$ cells) is shown in Figure 6. As shown by the model, after a very intense cascading event, coastal waters can reach the base of the slope, at depths in excess of $1500 \mathrm{~m}$. Bottom currents associated with this process are gravity currents whose intensity is proportional to the bathymetric slope. The acceleration of the current at the end of the shelf, first between 100 and 200 $\mathrm{m}$ depth, and then beyond $200 \mathrm{~m}$ inside the canyon, can generate flow velocities above $1 \mathrm{~m} \mathrm{~s}^{-1}$. Highest current speeds are found on the southern part of the canyon head and the upper canyon, where the dense water vein penetrates with a significant angle of incidence with respect to the isobaths. Further downstream, under the action of the Coriolis force that deflects the current to the right, the dense water vein is progressively flattened along the southern flank of the canyon, which produces a decrease of the current strength. Currents of up to $30 \mathrm{~cm} \mathrm{~s}^{-1}$ are also present on the external part of shelf, corresponding to water masses less dense than those that penetrate in the canyon. Regarding the realism of the simulation, currents above $1 \mathrm{~m} \mathrm{~s}^{-1}$ were measured in February 2012 at depths of $1000 \mathrm{~m}$ in the canyon axis, with a current meter located $23 \mathrm{~m}$ above the seafloor (Sanchez-Vidal et al., 2015). 
This would indicate that the results shown here could be underestimating the maximum current speeds that can be reached during cascading events.

\subsection{Interaction of litter with cold-water corals and other sessile fauna}

A total of 335 colonies of cold-water corals were identified in the canyon head, of which 302 Madrepora oculata, 26 Dendrophyllia cornigera and 7 Lophelia pertusa. Besides some variability at transect level, and independently of the species, more than $10 \%$ of the colonies had on average entangled longlines around them (Table 2). In most cases, longlines were observed hooked around the branches of the cold-water corals, regardless of the species (Figure 7). In general, most corals seemed to remain alive when having cables twisted around them. However, the distance of the camera to the colonies did not allow for a closer examination to determine the percentage of polyps affected and the level of harm produced. It was also impossible to determine how many broken branches resulted from the interaction between longlines and the coral colonies.

Some of the thickest longlines were also observed to act as substrate for several sessile species to live on, although for some of them precise identification was certainly difficult. Most species were bushy hydrozoans and bryozoans, together with the abundant polychaete Sabella pavonina, which was commonly observed attached to lines suspended over the seafloor (Figure 7c). Besides the effects produced by longlines on cold-water corals, other fishing gears were also observed to interact with benthic and demersal fauna. As an example, a large trammel net was found fully extended over the soft bottoms of the southern continental shelf (Dive 34; Figure 2I). As observed in the images, this net had at least two large spiny lobsters 
(Palinurus elephas) caught in it, one of which still alive, as well as other dead fishes impossible to identify. Also on the southern shelf, a large bottom trawl net was found lying over a sand plain with small outcropping rocks (Dive 36; Figure 2i). This trawl net was covered by a large number of small organisms (several species of sponges, ophiuroids and holothurians), indicating that it might have been lost for some years. Inside the submarine canyon, litter hotspots were generally observed over soft-bottom areas (Figure 5). Although the level of interaction was not quantified, the presence of these deposits seemed to overlap with the distribution of burrowing megafauna, including the anemone Cerianthus membranaceus (Figure 5a).

\section{Discussion}

\subsection{Seafloor litter provenance, abundance and distribution}

The popularity of Cap de Creus as a touristic attraction, with a significant increase in tourism and recreational boating during summer months (Lloret et al., 2008), and the historical relevance of its fishing grounds (Lloret and Riera, 2008), might help explain the amount and variety of litter objects encountered on its shelf and submarine canyon. Plastic was by far $(80 \%)$ the most common material that made up urban litter items. This situation is similar to that encountered in most shelf and slope environments of the European continent, both in the Atlantic (e.g. Neves et al., 2015; Moriarty et al., 2016; van den Beld et al., 2017; Maes et al., 2018) and the Mediterranean Sea (e.g. García-Rivera et al., 2018; Gerigny et al., 2019; Spedicato et al., 2019). Most items were small sized, and included plastic bags and bottles, but also clothes and other daily use objects. These items were possibly brought from 
surrounding areas by the wind or terrestrial run-off mainly during torrential events (Rech et al., 2014), or even discarded directly on beaches or at sea (Tubau et al., 2015). However, due to the particularities of the Gulf of Lion, the likelihood of an allochthonous origin of at least part of the lighter fraction should not be ruled out, with items reaching the sea from rivers that discharge in other parts of the gulf (Castro-Jiménez et al., 2019) and transported following the dominant water circulation patter (Millot, 1990). Conversely, the presence of some very large items such as fuel drums and car tires are an indication of intentional dumping, likely from the side or the back of vessels, a practice already identified in other areas of Europe's seas (e.g. Mordecai et al., 2011; Strafella et al., 2015). Although it is difficult to determine how long these objects have been at the seafloor, their presence might relate to practices that were more common in past decades, when the legislation on ocean dumping was less restrictive and the collection of waste by port authorities was not as widespread as it is nowadays (MARPOL, 1988).

The overall density of 110 litter items ha $^{-1}$ registered in Cap de Creus is of a similar magnitude to that found in the close-by submarine canyon of La Fonera, located only $50 \mathrm{~km}$ south (150 items ha ${ }^{-1}$; Tubau et al., 2015). However, imaging studies carried in other shelf and upper slope areas of the Mediterranean have reported litter densities up to one order of magnitude higher than those found in Cap de Creus, for example in the Ligurian basin (1500 items ha ${ }^{-1}$, Enrichetti et al., 2020 and Bo et al., 2014) and the Tyrrhenian Sea (1200 items ha ${ }^{-1}$, Angiolillo et al., 2015). Such differences must be attributed to the higher number of abandoned fishing gears that can be found on the seabed of the Central Mediterranean, where deep rocky 
banks and submarine canyons are highly frequented by local fishermen (e.g. Angiolillo et al., 2015; Cau et al., 2017; Consoli et al., 2019; Enrichetti et al., 2020). In Cap de Creus, densities of ALDFG peaked at the canyon head (150$400 \mathrm{~m}$ ), where more than $90 \%$ of litter items encountered were fishing-related. This situation was primarily associated to the large number of entangled longlines observed in the images, which generated an average density of 219 lines $\mathrm{ha}^{-1}$ for the canyon head. Very high abundances, in excess of 1000 lines $\mathrm{ha}^{-1}$, were reported in some spots, being Dive 9 the most characteristic example, with 119 lines annotated in a transect of less than $500 \mathrm{~m}$ in length. This situation seems to relate directly to the artisanal fishery that has been practiced in the area for a long time (Lloret and Riera, 2008), and even though the number of active longlining boats has steadily declined during the past decades (Gómez et al., 2006), its imprint remains visible in the steepest areas of the canyon head. As in Cap de Creus, the presence of lost longlines has become very common in seamounts and submarine canyons worldwide since these gears get easily entangled on hard grounds (Macfadyen et al., 2009; Pham et al., 2013). Lost lines and cables have now been reported in almost all submarine canyons across European continental margins, such as the canyon system of the Gulf of Lion (Fabri et al., 2014; Gerigny et al., 2019), the Bay of Biscay (van den Beld et al., 2016) and those of Portugal (Oliveira et al., 2015). Data comparisons with the remaining submarine canyons of the gulf are not straightforward, since litter abundance in these areas, although collected form ROV images, is expressed in items per linear km. As reported by Fabri et al. (2014), the submarine canyons of the Gulf of Lion had peak values of 4 fishing gears per linear $\mathrm{km}$, most of which concentrated at depths 
of 250-350 m. A simple transformation of our data to these units yields 45.5 items $\mathrm{km}^{-1}$ for Cap de Creus canyon head (150-400 m depth), a value 11 times higher than that reported in Lacaze-Duthiers Canyon, where the abovementioned peak value of Fabri's was encountered. This submarine canyon is the closest to Cap de Creus, and the proximity of both canyons to several fishing harbors and the high productivity of this part of the gulf may explain such large differences between them and the remaining canyons of the gulf.

Other much less abundant types of fishing gear consisted of a few trammel nets, mostly entangled on small rocky outcrops on the flat sandy areas of the southern shelf, and some large bottom trawl nets lying on shelf and middle canyon soft muddy bottoms. It is in these two domains where most bottom trawling takes place eased by soft bottom conditions, allowing medium-sized trawlers to easily swipe the seabed. Although accidental entanglement is significantly reduced in such environments, with rare rocky outcrops, trammel and bottom-trawling nets may represent in some places a significant contribution to seafloor ALDFG (Macfadyen et al., 2009).

\subsection{Seafloor litter transport}

Urban litter items showed a very clear spatial distribution pattern, with densities rapidly increasing with water depth (Figure 3). The deepest domain explored (i.e. the middle canyon, from 1000 to $1600 \mathrm{~m}$ depth) was the one showing the highest density of urban litter items (188 items ha $\left.{ }^{-1}\right), 25$ times higher than on the mid and outer continental shelf $\left(7.2\right.$ items ha $^{-1}$; see Section 3.2). A similar situation has been described in other deep-sea areas of the Mediterranean Sea, where large accumulations of debris appears below 1300-1500 m depth, such as the submarine canyons in the Messina Strait 
(Pierdomenico et al., 2019) or the abyssal plains of the Sardinian margin (Cau et al., 2018).

Beyond the topographic trap effect driven by gravity of submarine canyons, the litter distribution observed in Cap de Creus Canyon, with much more urban litter items in distal deeper areas than on the shore-proximal shallower shelf, must be explained by the dynamics of local bottom currents. Evidence indicates that the strong currents that recurrently sweep out the seafloor off Cap de Creus peninsula (Canals et al., 2006; Ulses et al., 2008; Durrieu de Madron et al., 2013) must be the causative process for such an asymmetric distribution, as they have the capability to carry light urban litter items towards the deepest parts of the submarine canyon, which ultimately becomes an accumulation area. Indeed, erosive and tractive features over the continental shelf embracing the Cap de Creus Canyon and on the canyon southern wall and floor have been also related to sediment-laden, strong bottom flows generated by dense shelf water cascading (Canals et al., 2006; Lastras et al., 2007; Puig et al., 2008; Durán et al., 2014; Ribó et al., 2018). In situ near bottom (i.e. $30 \mathrm{~m}$ above bottom) current speeds within Cap de Creus Canyon measured at the occasion of dense shelf water cascading events during the last two decades illustrate marine litter transport patterns to the deep (Canals et al., 2006; Sanchez-Vidal et al., 2015). Large volumes of dense water form over the continental shelf of the Gulf of Lion when strong, persistent, cold and dry northerly winds enhance heat losses and cool off shelf surface waters, thus increasing their density. The dense shelf water then flows cyclonically over most of the shelf on a southwestwards-oriented regional circulation pattern. Flow lines converge and flow accelerates because of an obstacle 
effect produced Cap de Creus Peninsula, in the southwestern part of the gulf. The cape deviates the water course seawards, thus flowing down into the canyon head an upper course, also favored by the narrowing of the shelf shoreward of the canyon head (Figure 6). This process has been identified in many locations both in the Mediterranean Sea and the world ocean (Ivanov et al., 2004; Durrieu de Madron et al., 2005; Canals et al., 2009). Amongst the many canyons in the Gulf of Lions and on the North Catalan continental margin, Cap de Creus Canyon is the main outlet for dense shelf water cascading (and everything else that comes with), which is undoubtedly favored by its location with respect to the regional circulation ahead of the promontory formed by the Cap de Creus Peninsula (Canals et al., 2006). The erosional, tractive and depositional effects of these cascades on the canyon floor are clearly visible down to its mouth at $2140 \mathrm{~m}$ depth and beyond are illustrated by giant furrows, an incised thalweg, scours, sediment bars and coarse sand deposits (Lastras et al., 2007).

During such events, dense cascading shelf waters carry huge amounts of resuspended sediments downcanyon, together with organic matter and pollutants advected from the continental shelf (Guillén et al., 2006; Bourrin et al., 2008; Sanchez-Vidal et al., 2008, 2015; Salvadó et al., 2012, 2017). The finest fraction of such sedimentary flows can stay in suspension for long periods of time (i.e. some years) thereby forming hundreds of meters thick nepheloid layers extending over the slope and deep basin (Puig et al., 2013). This proves that light micro- and macrolitter (e.g. plastics) lying on the continental shelf may easily be swept and transported all the way down the Cap de Creus submarine canyon. Because of their intrinsic properties, plastic 
items (bags, bottles, cups, fragments) with low drag area behave noncohesively in marine conditions. Turbulent bottom cascading currents are able to provide the shear stress needed to resuspend and transport these objects, either as bed load (relatively heavier items), or by saltation or suspension (relatively lighter items). Conversely, longlines and ropes, and nets would not have been dragged downcanyon since they usually are strongly caught around outcropping rocks, hard grounds and cold-water coral colonies (see Sections 3.2 and 3.4 ) in the canyon head, thus severely limiting chances for transportation. Other ALDFG items, such as bottom trawling nets found on soft bottoms, would seem too big and heavy to be transported by those currents. However, it has been observed for these currents to cause about $400 \mathrm{~kg}$ mooring anchor weights left on the sand-filled canyon thalweg to move down by several kilometers while dragging the entire mooring just in few days (Puig et al., 2008), which illustrates the tremendous transport capacity these currents have. In fact, the highest number of bottom trawl nets reported in this study (Dive 42) appeared in an area of the canyon head that according to VMS records (unpublished data) is not frequented by trawlers. This could be an indication that bottom trawl nets abandoned on the northern shelf could be pushed towards the canyon head, where they could end up entangled around rocks. All the above provides a robust explanation of the litter class sorting observed in Cap de Creus Canyon, with ALDFG concentrating in the canyon head and lighter objects being washed away to the deepest part of the canyon floor. Tubau et al. (2015) had formerly suggested the above-described litter funneling process towards deeper canyon reaches, which then become litter accumulation zones. The results presented here bring in a wealth of data from 
shallower domains than those considered in Tubau's work, thus allowing an extensive comparison and providing and improved understanding of the magnitude of the cleaning role of the continental shelf by high-energy natural oceanographic processes. Finally, it could be hypothesized that these processes may have an even larger influence on the distribution of microplastics at larger scale, since small plastic particles could be easily washed away through submarine canyons towards deeper areas, generating accumulations areas beyond $2000 \mathrm{~m}$, as already suggested by Sanchez-Vidal et al. (2018). The presence of large deposits of microplastics on the deep sea could have far reaching consequences than previously thought, especially if they become part of the diet of some deep-sea species (Carreras-Colom et al., 2018; Cau et al., 2019), which could introduce this fragmented plastic into the food chain and eventually generate problems of food security.

\subsection{Interactions of longlines with cold-water corals}

It has been recognized that longline fishing has a far smaller impact on vulnerable marine ecosystems than commercial bottom trawling (Pham et al., 2014a). This does not mean that its effects over the benthic fauna should be overlooked, especially in coral rich areas where an intense activity of bottom longlining exists (Bo et al., 2014; Consoli et al., 2019). We have assessed the impact of abandoned longlines on the three main cold-water coral species occurring in Cap de Creus Canyon as a proxy for the level of impact this fishing practices may have over the benthic community in its entirety. Whereas the number of coral colonies affected differed from one dive to another, the highest percentage of entanglement occurred in areas where the density of longlines was higher. Overall, $10 \%$ of all cold-water colonies 
identified in the video footage had lines entangled around them, a situation that could lead to suffocation, branch breakage, abrasion, epibiosis, infection and ultimately the death of colonies (Galgani et al., 2018). Compared to other locations in the Mediterranean Sea, where up to three times more corals have been reported to be affected by longlines (Angiolillo et al., 2015; Bo et al., 2014), the value we have found in Cap de Creus Canyon appears rather low. However, video footage may offer a partial view of the real impact caused by longlines, as it provides limited information on how many colonies are partially broken and no information at all on colonies that have been fully removed from their natural habitat due to such fishing practices. If properly recorded, by-catch data from fishing boat logbooks could bring complementary information to better assess the percentage of coral colonies broken or entirely removed by longlining yearly. It seems also plausible that loose longlines, ropes and net fragments, together with their loose ends and hanging sections, could be swung and moved down by the strong bottom currents measured in the Cap de Creus canyon head and beyond. This might favor secondary entanglement around already entangled colonies and on new colonies, with the associated damage this could cause.

\subsection{Management implications}

As part of the ecosystem-based approach to management that should be implemented in the SCI "South-West Gulf of Lions canyons system", local and national authorities may consider using the results of this study when designing mitigation measures to tackle the threat posed by the accumulation of marine litter over the seabed. In this sense, maintaining or improving the quality of the marine ecosystem of Cap de Creus could only be achieved by 
means of (1) a drastic reduction of the litter inputs (i.e. strict control of land and sea-based sources) and possibly (2) through specific actions set to remove some of the objects currently found over the seabed. The development of such measures would be in line with initiatives already launched at the European level (e.g. European Commission, 2019), which are now seeking solutions for the removal of existing marine litter (notably plastics and microplastics) to limit the damage over the benthic ecosystem. In the specific case of Cap de Creus, since all litter items identified in the video footage are now accurately georeferenced, it could be possible to attempt the recovery of some of the debris found in certain accumulation areas or litter hotspots, especially in trawlable grounds inside the submarine canyon. In these cases, each attempt should weight the benefits of removing large amounts of marine litter against the potential impact on the benthic fauna produced by trawl net, especially in those areas that are currently free of trawling. The video images used together with the multibeam bathymetry of the submarine canyon could be a powerful tool to assess the feasibility of each action and the consequences of its implementation.

In the same way, abandoned trammel and trawl nets could also be retrieved to reduce future damage. Although these procedures are much simpler in shallow waters, where SCUBA divers can operate generating the minimum damage possible (see a protocol for the extraction of lost nets in Hereu and Ylla, 2017), there exists the possibility of using, for instance, a vessel-towed "creeper" (Graham et al., 2009) to retrieve selected nets from deeper softbottom areas. Such an operation, which has proven satisfactory to remove gillnets in deep-sea areas in Norway and Rockall and Porcupine banks (Large 
et al., 2009), would be relatively cheap and simple to implement. Joint actions with local fishermen, who have a strong knowledge of the seabed after many years of experience, could facilitate the retrieval of ALDFG, while helping raising awareness of the impacts that their activities may have over the benthic ecosystem and, ultimately, in the catches they are interested in. Initiatives such as Fishing for Litter (www.fishingforlitter.org.uk), Projecte Marviva

(http://residus.gencat.cat/ca/ambits dactuacio/tipus de residu/deixalles-

marines/projectes/projecte-marviva/) and Projecte Evitem la Pesca Fantasma (http://www.pescafantasma.cat/) could serve as useful references for the retrieval of abandoned fishing arts.

Finally, and following the demands of the MSFD, the data provided in this study should be view as a robust reference point in order to monitor the temporal evolution of the marine area, and also to determine the effectiveness of management and mitigation actions developed by regional and national authorities in the forthcoming years.

\section{Funding}

The European Project HERMES (Goce-CT-2005-511234-I), the Spanish Project DEEP CORAL (CTM2005-07756-C02-02/MAR) and the Acciones Complementarias (CTM2007-28758-E/MAR) supported the 2007 cruise on board R/V Garcia del Cid with the manned submersible JAGO. Fundació "la Caixa" sponsored the PROMARES ROV cruise of the University of Barcelona, for which IEO and CSIC provided the Liropus 2000 ROV and R/V Sarmiento de Gamboa, respectively. The EU project Life+ Indemares 
(LIFE07/NAT/E/000732) funded the 2009, 2010 \& 2012 cruises on board R/V Garcia del Cid and the littoral surveys with Bleeper EVO in 2009 and 2013. Numerical simulations were performed using HPC resources from the CALMIP platform (French region Occitanie) under grant P09115. The SYMPHONIE model is distributed by the SIROCCO group (https://sirocco.obs-mip.fr). This work also is a contribution of project IDEM (Implementation of the MSFD to the DEep Mediterranean Sea, ref. $11.0661 / 2017 / 750680 /$ SUB/ENV.C2) funded by DG Environment of the European Commission, and the research network Red Española sobre BAsuras MARinas (BAMAR, CGL2016-81854-REDT) coordinated by the University of Barcelona.

\section{Acknowledgements}

The authors would like to thank the crew of the research vessels and all the scientists and technicians that helped during the different surveys. We are grateful for the professionality shown by Gavin Newman (ROV pilot) and the members of the JAGO Team Jurgen Schauer and Karen Hissman during the acquisition of the video footage during the DEEP CORAL and INDEMARES cruises. Generalitat de Catalunya autonomous government funding to $\mathrm{CRG}$ Marine Geosciences is also acknowledged (Ref. 2017 SGR 315).

\section{References}

Addamo, A.M., Vertino, A., Stolarski, J., García-Jiménez, R., Taviani, M., Machordom, A., 2016. Merging scleractinian genera: the overwhelming 
genetic similarity between solitary Desmophyllum and colonial Lophelia. BMC Evol Biol 16, 108. https://doi.org/10.1186/s12862-016-0654-8

Agamuthu, P., Mehran, S.B., Norkhairah, A., Norkhairiyah, A., 2019. Marine debris: A review of impacts and global initiatives. Waste Manag. Res 37, 9871002. https://doi.org/10.1177/0734242X19845041.

Angiolillo, M., di Lorenzo, B., Farcomeni, A., Bo, M., Bavestrello, G., Santangelo, G., Cau, A., Mastascusa, V., Cau, A., Sacco, F., Canese, S., 2015. Distribution and assessment of marine debris in the deep Tyrrhenian Sea (NW Mediterranean Sea, Italy). Mar. Poll. Bull. 92, 149-159. https://doi.org/10.1016/j.marpolbul.2014.12.044.

Beaumont, N.J., Aanesen, M., Austen, M.C., Börger, T., Clark, J.R., Cole, M., Hooper, T., Lindeque, P.K., Pascoe, C., Wyles, K.J., 2019. Global ecological, social and economic impacts of marine plastic. Mar. Poll. Bull. 142, 189-195. https://doi.org/10.1016/i.marpolbul.2019.03.022.

Bo, M., Bava, S., Canese, S., Angiolillo, M., Cattaneo-Vietti, R., Bavestrello, G., 2014. Fishing impact on deep Mediterranean rocky habitats as revealed by ROV investigation. Biol. Cons. 171, 167-176. https://doi.org/10.1016/j.biocon.2014.01.011.

BOE, 1998. Ley 4/1998, de 12 de marzo, de Protección de Cap de Creus. Boletín Oficial del Estado, Madrid. 
BOE, 2014. Orden AAA/1299/2014, de 9 de julio, por la que se aprueba la propuesta de inclusión en la lista de lugares de importancia comunitaria de la Red Natura 2000 de los espacios marinos ESZZ16001 Sistema de cañones submarinos occidentales del Golfo de León, ESZZ16002 Canal de Menorca, ESZZ12002 Volcanes de fango del Golfo de Cádiz y ESZZ12001 Banco de Galicia. Boletín Oficial del Estado, Madrid.

Bourrin, F., Friend, P.L., Amos, C.L., Manca, E., Ulses, C., Palanques, A., Durrieu de Madron, X., Thompson, C.E.L., 2008. Sediment dispersal from a typical Mediterranean flood: The Têt River, Gulf of Lions. Cont. Shelf Res. 28, 1895-1910. https://doi.org/10.1016/i.csr.2008.06.005.

Buhl-Mortensen, L. \& Buhl-Mortensen, P., 2017. Marine litter in the Nordic Seas: Distribution composition and abundance. Mar. Poll. Bull. 125, 260-270. https://doi.org/10.1016/j.marpolbul.2017.08.048.

Canals, M., Casamor, J.L., Lastras, G., Monaco, A., Acosta, J., Berné, S., Loubrieu, B., Weaver, P., Grehan, A., Dennielou, B., 2004. The Role of Canyons on Strata Formation. Oceanogr. 17, 80-91. https://doi.org/10.5670/oceanog.2004.06.

Canals, M., Puig, P., Durrieu de Madron, X., Heussner, S., Palanques, A., Fabres, J., 2006. Flushing submarine canyons. Nature 444, 354-357. https://doi.org/10.1038/nature05271. 
Canals, M., Danovaro, R., Heussner, S., Lykousis, V., Puig, P., Trincardi, F.,

Calafat, A.M., Durrieu de Madron, X., Palanques, A., Sanchez-Vidal, A., 2009.

Cascades in Mediterranean Submarine Grand Canyons. Oceanogr. 22 (1), 26-43. https://doi.org/10.5670/oceanog.2009.03.

Carreras-Colom, E., Constenla, M., Soler-Membrives, A., Cartes, J. E., Baeza, M., Padrós, F., Carrassón, M., 2018. Spatial occurrence and effects of microplastic ingestion on the deep-water shrimp Aristeus antennatus. Mar. Pollut. Bull. 133, 44-52. https://doi.org/10.1016/j.marpolbul.2018.05.012.

Castro-Jiménez, J., González-Fernández, D., Fornier, M., Schmidt, N., Sempéré, R., 2019. Macro-litter in surface waters from the Rhone River: Plastic pollution and loading to the NW Mediterranean Sea. Mar. Poll. Bull. 146, 60-66. https://doi.org/10.1016/j.marpolbul.2019.05.067.

Cau, A., Alvito, A., Moccia, D., Canese, S., Pusceddu, A., Rita, C., Angiolillo, M., Follesa, M.C., 2017. Submarine canyons along the upper Sardinian slope (Central Western Mediterranean) as repositories for derelict fishing gears. $\begin{array}{llll}\text { Mar. Poll. } & \text { Bull. }\end{array}$ https://doi.org/10.1016/j.marpolbul.2017.09.010.

Cau, A., Avio, C. G., Dessì, C., Follesa, M. C., Moccia, D., Regoli, F., Pusceddu, A., 2019. Microplastics in the crustaceans Nephrops norvegicus 
and Aristeus antennatus: Flagship species for deep-sea environments? Environ. Pollut. 255, 113107. https://doi.org/10.1016/j.envpol.2019.113107.

Cau, A., Bellodi, A., Moccia, D., Mulas, A., Pesci, P., Cannas, R., Pusceddu, A., Follesa, M.C., 2018. Dumping to the abyss: single-use marine litter invading bathyal plains of the Sardinian margin (Tyrrhenian Sea). Mar. Poll. Bull. 135, 845-851. https://doi.org/10.1016/j.marpolbul.2018.08.007.

Consoli, P., Andaloro, F., Altobelli, C., Battaglia, P., Campagnuolo, S., Canese, S., Castriota, L., Cillari, T., Falautano, M., Pedà, C., Perzia, P., Sinopoli, M., Vivona, P., Scotti, G., Esposito, V., Galgani, F., Romeo, T., 2018. Marine litter in an EBSA (Ecologically or Biologically Significant Area) of the central Mediterranean Sea: Abundance, composition, impact on benthic species and basis for monitoring entanglement. Environ. Pollut. 236, 405415. https://doi.org/10.1016/j.envpol.2018.01.097.

Consoli, P., Romeo, T., Angiolillo, M., Canese, S., Esposito, V., Salvati, E., Scotti, G., Andaloro, F., Tunesi, L., 2019. Marine litter from fishery activities in the Western Mediterranean sea: The impact of entanglement on marine animal forests. Environ. Pollut. 249, 472-481. https://doi.org/10.1016/i.envpol.2019.03.072.

Council of the European Union, 2008. Directive 2008/56/EC of the European Parliament and of the Council of 17 June 2008, establishing a framework for 
community action in the field of marine environmental policy (Marine Strategy Framework Directive), Official Journal of the European Union.

Courtene-Jones, W., Quinn, B., Ewins, C., Gary, S.F., Narayanaswamy, B.E., 2018. Consistent microplastic ingestion by deep-sea invertebrates over the last four decades (1976-2015), a study from the North East Atlantic. Environ. Pollut. 244, 503-512. https://doi.org/10.1016/j.envpol.2018.10.090.

Dominguez-Carrió, C. (2018) ROV-based ecological study and management proposals for the offshore Marine Protected Area of Cap de Creus (NW Mediterranean). PhD Thesis, Universitat de Barcelona.

Durán, R., Canals, M., Sanz, J.L., Lastras, G., Amblas, D., Micallef, A., 2014. Morphology and sediment dynamics of the northern Catalan continental shelf, northwestern Mediterranean Sea. Geomorph. 204, 1-20. http://doi.org/10.1016/j.geomorph.2012.10.004.

Durrieu de Madron, X., Zervakis, V., Theocharis, A., Georgopoulos, D., 2005. Comments on "Cascades of dense water around the world ocean". Progr. Oceanogr. 64, 83-90. https://doi.org/10.1016/j.pocean.2004.08.004.

Durrieu de Madron, X., Houpert, L., Puig, P., Sanchez-Vidal, A., Testor, P., Bosse, A., Estournel, C., Somot, S., Bourrin, F., Bouin, M.N., Beauverger, M., Beguery, L., Calafat, A., Canals, M., Coppola, L., Dausse, D., D’Ortenzio, F., Font, J., Heussner, S., Kunesch, S., Le Goff, H., Martín, J., Mortier, L., 
Palanques, A., Raimbault, P., 2013. Interaction of dense shelf water cascading and open-sea convection in the northwestern Mediterranean during winter 2012. Geophys. Res. Lett. 40, 1379-1385. https://doi.org/10.1002/grl.50331.

European Commission, 2019. Horizon 2020 Work Programme 2018-2020. 9. Food security, sustainable agriculture and forestry, marine, maritime and inland water research and the bioeconomy. European Commission Decision C (2019) 4575 of 2 July 2019. Topic CE-FNR-09-2020: Pilot action for the removal of marine plastics and litter.

Enrichetti, F., Dominguez-Carrió, C., Toma, M., Bavestrello, G., Canese, S., Bo, M., 2020. Assessment and distribution of seafloor litter on the deep Ligurian continental shelf and shelf break (NW Mediterranean Sea). Mar. Poll. Bull. 151, 110872. https://doi.org/10.1016/j.marpolbul.2019.110872.

Fabri, M.-C., Pedel, L., Beuck, L., Galgani, F., Hebbeln, D., Freiwald, A., 2014. Megafauna of vulnerable marine ecosystems in French mediterranean submarine canyons. Spatial distribution and anthropogenic impacts. DeepSea Res. Pt II 104, 184-207. https://doi.org/10.1016/j.dsr2.2013.06.016.

Galgani, F., Hanke, G., Maes, T., 2015. Global Distribution, Composition and Abundance of Marine Litter, in: Bergmann, M., Gutow, L., Klages, M. (Eds.), Marine Anthropogenic Litter. Springer, Cham, pp. 29-56. https://doi.org/10.1007/978-3-319-16510-3 2. 
Galgani, F., Hanke, G., Werner, S., De Vrees, L., 2013. Marine litter within the European Marine Strategy Framework Directive. ICES J. Mar. Sci. 70, 10551064. https://doi.org/10.1093/icesjms/fst122.

Galgani, F., Pham, C.K., Claro, F., Consoli, P., 2018. Marine animal forests as useful indicators of entanglement by marine litter. Mar. Poll. Bull. 135, 735738. https://doi.org/10.1016/j.marpolbul.2018.08.004.

García-Rivera, S., Lizaso, J.L.S., Millán, J.M.B., 2018. Spatial and temporal trends of marine litter in the Spanish Mediterranean seafloor. Mar. Poll. Bull. 137, 252-261. https://doi.org/10.1016/i.marpolbul.2018.09.051.

Gerigny, O., Brun, M., Fabri, M.-C., Tomasino, C., Le Moigne, M., Jadaud, A., Galgani, F., 2019. Seafloor litter from the continental shelf and canyons in French Mediterranean Water: Distribution, typologies and trends. Mar. Poll. Bull. 146, 653-666. https://doi.org/10.1016/j.marpolbul.2019.07.030.

Gili, J.M., Madurell, T., Requena, S., Orejas, C., Gori, A., Purroy, A., Dominguez-Carrió, C., Lo lacono, C., Isla, E., Lozoya, J.P., Grinyó, J. (2011) Caracterización física y ecológica del área marina del Cap de Creus: Informe final área LIFE+ INDEMARES (LIFE07/NAT/E/000732). Instituto de Ciencias del Mar/CSIC (Barcelona). Coordinación: Fundación Biodiversidad, Madrid. 272pp. 
Gilman, E.L., Chopin, F., Suuronen, P., Kuemlangan, B., 2016. Abandoned, lost and discarded gillnets and trammel nets. (No. 600), FAO Fisheries and Aquaculture Technical Paper. Food and Agriculture Organization of the United Nations, Rome.

Gómez, S., Lloret, J., Demestre, M., Riera, V., 2006. The decline of the artisanal fisheries in Mediterranean coastal areas: the case of Cap de Creus (Cape Creus).

Coast. Manage.

34 , $217-232$ https://doi.org/10.1080/08920750500531389.

Graham, N., Hareide, N.R., Large, P.A., MacMullen, P., Mulligan, M., Randall, P.J., Rihan, D.J., Peach, D.J., 2009. Recuperation of fishing nets lost or abandoned at sea (No. FISH/2006/15/Lot No. 5). European Commission Directorate.

Guillén, J., Bourrin, F., Palanques, A., Durrieu de Madron, X., Puig, P., Buscail, R., 2006. Sediment dynamics during wet and dry storm events on the Têt inner shelf (SW Gulf of Lions). Mar. Geol. 234, 129-142. https://doi.org/10.1016/..margeo.2006.09.018.

Hereu, B., Ylla, J., 2017. Protocol per a l'extracció d'arts de pesca perduts a la costa catalana. Direcció General de Pesca i Afers Marítims, Generalitat de Catalunya. $42 \mathrm{pp}$. 
Herrmann, M.J., Sevault, F., Beuvier, J., Somot, S., 2010. What induced the exceptional 2005 convection event in the northwestern Mediterranean basin? Answers from a modeling study. J. Geophys. Res. 115, C12051-19. https://doi.org/10.1029/2010JC006162.

Herrmann, M.J., Somot, S., 2008. Relevance of ERA40 dynamical downscaling for modeling deep convection in the Mediterranean Sea. Geophys. Res. Lett. 35, L04607-5. https://doi.org/10.1029/2007GL032442.

Iñiguez, M.E., Conesa, J.A., Fullana, A., 2016. Marine debris occurrence and treatment: A review. Renew. Sust. Energ. Rev. 64, 394-402. https://doi.org/10.1016/j.rser.2016.06.031.

Ivanov, V.V., Shapiro, G.I., Huthnance, J.M., Aleynik, D.L., Golovin, P.N., 2004. Cascades of dense water around the world ocean. Progr. Oceanogr. 60, 47-98. https://doi.org/10.1016/i.pocean.2003.12.002.

Jambeck, J.R., Geyer, R., Wilcox, C., Siegler, T.R., Perryman, M., Andrady, A., Narayan, R., Law, K.L., 2015. Plastic waste inputs from land into the ocean. Science 347, 768-771. https://doi.org/10.1126/science.1260352.

Kühn, S., Bravo Rebolledo, E.L., van Franeker, J.A., 2015. Deleterious effects of litter on marine life, in: Bergmann, M., Gutow, L., Klages, M. (Eds.), Marine Anthropogenic Litter. Springer, Cham, pp. 75-116. https://doi.org/10.1007/978-3-319-16510-3 4. 
Laist, D.W., 1987. Overview of the biological effects of lost and discarded plastic debris in the marine environment. Mar. Poll. Bull. 18, 319-326. https://doi.org/10.1016/S0025-326X(87)80019-X.

Large, P.A., Graham, N.G., Hareide, N.-R., Misund, R., Rihan, D.J., Mulligan, M.C., Randall, P.J., Peach, D.J., McMullen, P.H., Harlay, X., 2009. Lost and abandoned nets in deep-water gillnet fisheries in the Northeast Atlantic: retrieval exercises and outcomes. ICES J. Mar. Sci. 66, 323-333. https://doi.org/10.1093/icesjms/fsn220.

Lastras, G., Canals, M., Urgeles, R., Amblas, D., Ivanov, M., Droz, L., Dennielou, B., Fabrés, J., Schoolmeester, T., Akhmetzhanov, A., Orange, D., García-García, A., 2007. A walk down the Cap de Creus canyon, Northwestern Mediterranean Sea: Recent processes inferred from morphology and sediment bedforms. Mar. Geol. 246, 176-192. https://doi.org/10.1016/..margeo.2007.09.002.

Lloret, J., Riera, V., 2008. Evolution of a Mediterranean coastal zone: human impacts on the marine environment of Cape Creus. Environ. Manage. 42, 977-988. https://doi.org/10.1007/s00267-008-9196-1.

Lloret, J., Zaragoza, N., Caballero, D., Riera, V., 2008. Impacts of recreational boating on the marine environment of Cap de Creus (Mediterranean Sea). 
Ocean

Coast.

Manage.

51

$749-754$.

https://doi.org/10.1016/j.ocecoaman.2008.07.001.

MacFadyen, G., Huntington, T., and Cappell, R. (2009). Abandoned, Lost or Otherwise Discarded Fishing Gear. UNEP Regional Seas Reports and Studies No.185; FAO Fisheries and Aquaculture Technical Paper, No. 523. Rome, UNEP/FAO. 2009. 115p.

Maes, T., Barry, J., Leslie, H.A., Vethaak, A.D., Nicolaus, E.E.M., Law, R.J., Lyons, B.P., Martinez, R., Harley, B., Thain, J.E., 2018. Below the surface: Twenty-five years of seafloor litter monitoring in coastal seas of North West Europe (1992-2017). Sci. Total Environ. 630, 790-798. https://doi.org/10.1016/i.scitotenv.2018.02.245.

MARPOL (International Convention for the Prevention of Pollution from Ships) 1988. Annex V Prevention of Pollution by Garbage from Ships.

Marsaleix, P., Auclair, F., Duhaut, T., Estournel, C., Nguyen, C., Ulses, C., 2012. Alternatives to the Robert-Asselin filter. Ocean Model. 41, 53-66. https://doi.org/10.1016/j.ocemod.2011.11.002.

Marsaleix, P., Auclair, F., Estournel, C., 2009. Low-order pressure gradient schemes in sigma coordinate models: The seamount test revisited. Ocean Model. 30, 169-177 https://doi.org/10.1016/j.ocemod.2009.06.011. 
Marsaleix, P., Auclair, F., Floor, J.W., Herrmann, M.J., Estournel, C., Pairaud, I., Ulses, C., 2008. Energy conservation issues in sigma-coordinate freesurface ocean models. Ocean Model. 20, 61-89. https://doi.org/10.1016/j.ocemod.2007.07.005.

Mikolajczak, G., Estournel, C., Ulses, C., Marsaleix, P., Bourrin, F., Martin, J., Pairaud, I., Puig, P., Leredde, Y., Many; G., Seyfried, L., Durrieu de Madron, X., 2020. Impact of storms on residence times and export of coastal waters during a mild autumn/winter period in the Gulf of Lion. Cont. Shelf Res. 207, 104192. https://doi.org/10.1016/j.csr.2020.104192

Millot, C., 1990. The Gulf of Lions' hydrodynamics. Cont. Shelf Res. 10, 885894. https://doi.org/10.1016/0278-4343(90)90065-t.

Mordecai, G., Tyler, P.A., Masson, D.G., Huvenne, V.A.I., 2011. Litter in submarine canyons off the west coast of Portugal. Deep-Sea Res. Pt II 58, 2489-2496. https://doi.org/10.1016/j.dsr2.2011.08.009.

Moriarty, M., Pedreschi, D., Stokes, D., Dransfeld, L., Reid, D.G., 2016. Spatial and temporal analysis of litter in the Celtic Sea from Groundfish Survey data: Lessons for monitoring. Mar. Poll. Bull. 103, 195-205. https://doi.org/10.1016/i.marpolbul.2015.12.019. 
Neves, D., Sobral, P., Pereira, T., 2015. Marine litter in bottom trawls off the Portuguese coast. Mar. Poll. Bull. 99, 301-304. https://doi.org/10.1016/j.marpolbul.2015.07.044.

Oliveira, F., Monteiro, P., Bentes, L., Henriques, N.S., Aguilar, R., Gonçalves, J.M.S., 2015. Marine litter in the upper São Vicente submarine canyon (SW Portugal): Abundance, distribution, composition and fauna interactions. Mar. Poll. Bull. 97, 401-407. https://doi.org/10.1016/j.marpolbul.2015.05.060.

Orejas, C., Gori, A., Lo lacono, C., Puig, P., Gili, J.-M., Dale, M.R.T., 2009. Cold-water corals in the Cap de Creus canyon, northwestern Mediterranean: spatial distribution, density and anthropogenic impact. Mar. Ecol. Prog. Ser. 397, 37-51. https://doi.org/10.3354/meps08314.

Palanques, A., Durrieu de Madron, X., Puig, P., Fabres, J., Guillén, J., Calafat, A.M., Canals, M., Heussner, S., Bonnin, J., 2006. Suspended sediment fluxes and transport processes in the Gulf of Lion submarine canyons. The role of storms and dense water cascading. Mar. Geol. 234, 4361. https://doi.org/10.1016/j.margeo.2006.09.002.

Pasquini, G., Ronchi, F., Strafella, P., Scarcella, G., Fortibuoni, T., 2016. Seabed litter composition, distribution and sources in the Northern and Central Adriatic Sea (Mediterranean). Waste Manag. 58, 41-51. https://doi.org/10.1016/j.wasman.2016.08.038. 
Pham, C.K., Gomes-Pereira, J.N., Isidro, E.J., Santos, R.S., Morato, T., 2013. Abundance of litter on Condor seamount (Azores, Portugal, Northeast Atlantic). Deep-Sea Res. Pt II 98, 204-208. https://doi.org/10.1016/j.dsr2.2013.01.011.

Pham, C.K., Diogo, H., Menezes, G.M., Porteiro, F.M., Braga-Henriques, A., Vandeperre, F., Morato, T., 2014a. Deep-water longline fishing has reduced impact on Vulnerable Marine Ecosystems. Sci. Rep. 4, 4837. https://doi.org/10.1038/srep04837.

Pham, C.K., Ramirez-Llodra, E., Alt, C.H.S., Amaro, T., Bergmann, M., Canals, M., Company, J.B., Davies, J.S., Duineveld, G.C.A., Galgani, F., Howell, K.-L., Huvenne, V.A.I., Isidro, E., Jones, D.O.B., Lastras, G., Morato, T., Gomes-Pereira, J.N., Purser, A., Stewart, H., Tojeira, I., Tubau, X., Van Rooij, D., Tyler, P.A., 2014b. Marine litter distribution and density in European seas, from the shelves to deep basins. Plos One 9(4), e95839. https://doi.org/10.1371/journal.pone.0095839.

Pierdomenico, M., Casalbore, D., Chiocci, F.L., 2019. Massive benthic litter funnelled to deep sea by flash-flood generated hyperpycnal flows. Sci. Rep. 9, 5330. https://doi.org/10.1038/s41598-019-41816-8.

Poulier, G., Launay, M., Le Bescond, C., Thollet, F., Coquery, M., Le Coz, J., 2019. Combining flux monitoring and data reconstruction to establish annual budgets of suspended particulate matter, mercury and PCB in the Rhône 
River from Lake Geneva to the Mediterranean Sea. Sci. Total Environ. 658, 457-473. https://doi.org/10.1016/j.scitotenv.2018.12.075.

Puig, P., Palanques, A., Orange, D.L., Lastras, G., Canals, M., 2008. Dense shelf water cascades and sedimentary furrow formation in the Cap de Creus Canyon, northwestern Mediterranean Sea. Cont. Shelf Res. 28, 2017-2030. https://doi.org/10.1016/j.csr.2008.05.002.

Puig, P., Durrieu de Madron, X., Salat, J., Schroeder, K., Martín, J., Karageorgis, A.P., Palanques, A., Roullier, F., Lopez-Jurado, J.L., Emelianov, M., Moutin, T., Houpert, L., 2013. Thick bottom nepheloid layers in the western Mediterranean generated by deep dense shelf water cascading. Prog. Oceanogr. 111, 1-23. Doi: http://doi.org/10.1016/i.pocean.2012.10.003.

Rangel-Buitrago, N., Williams, A., Costa, M.F., de Jonge, V., 2020. Curbing the inexorable rising in marine litter: An overview. Ocean Coast. Manage. 188, 105133. http://doi.org/10.1016/j.ocecoaman.2020.105133.

Rech, S., Macaya-Caquilpán, V., Pantoja, J.F., Rivadeneira, M.M., Jofre Madariaga, D., Thiel, M., 2014. Rivers as a source of marine litter - A study from the SE Pacific. Mar. Poll. Bull. 82, 66-75. http://doi.org/10.1016/i.marpolbul.2014.03.019. 
Richardson, K., Hardesty, B.D., Wilcox, C., 2019. Estimates of fishing gear loss rates at a global scale: A literature review and meta-analysis. Fish Fish. 131, 9. http://doi.org/10.1111/faf.12407.

Ribó, M., Durán, R., Puig, P., Van Rooij, D., Guillén, J., Masqué, P., 2018. Large sediment waves over the Gulf of Roses upper continental slope (NW $\begin{array}{llll}\text { Mediterranean). } & \text { Mar. } & \text { Geol. } & \text { 84-96. }\end{array}$ https://doi.org/10.1016/j.margeo.2018.02.006.

Salvadó, J.A., Grimalt, J.O., López, J.F., Palanques, A., Heussner, S., Pasqual, C., Sanchez-Vidal, A., Canals, M., 2012. The role of dense shelf water cascading in the transfer of organochlorine compounds to open marine $\begin{array}{lllll}\text { waters. } & \text { Environ. } & \text { Sci. } & \text { Technol. } 46 & \text { (5), }\end{array}$ http://doi.org/doi.org/10.1021/es2038189.

Salvadó, J.A., López, J., Palanques, A., Heussner, S., Pasqual, C., SanchezVidal, A., Canals, M., Grimalt, J., 2017. Transfer of lipid molecules and polycyclic aromatic hydrocarbons to open marine waters by dense water

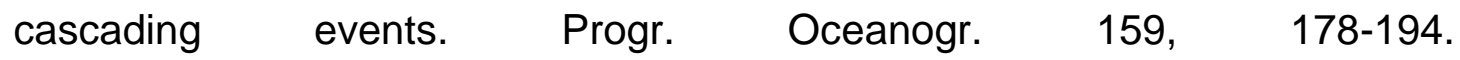
http://doi.org/10.1016/i.pocean.2017.10.002.

Sanchez-Vidal, A., Pasqual, C., Kerhervé, P., Calafat, A., Heussner, S., Palanques, A., Durrieu de Madron, X., Canals, M., Puig, P., 2008. Impact of dense shelf water cascading on the transfer of organic matter to the deep 
western Mediterranean basin. Geophys. Res. Lett. 35, L05605. http://doi.org/10.1029/2007GL032825.

Sanchez-Vidal, A., Llorca, M., Farré, M., Canals, M., Barceló, D., Puig, P., Calafat, A., 2015. Delivery of unprecedented amounts of perfluoroalkyl substances towards the deep-sea. Sc. Total Env. 526, 41-48. http://doi.org/10.1016/..scitotenv.2015.04.080.

Sanchez-Vidal, A., Thompson, R.C., Canals, M., de Haan, W.P., 2018. The imprint of microfibres in southern European deep seas. Plos One 13, e0207033-12. http://doi.org/10.1371/journal.pone.0207033.

Spedicato, M.T., Zupa, W., Carbonara, P., Fiorentino, F., Follesa, M.C., Galgani, F., García-Ruiz, C., Jadaud, A., loakeimidis, C., Lazarakis, G., Lembo, G., Mandic, M., Maiorano, P., Sartini, M., Serena, F., Cau, A., Esteban, A., Isajlović, I., Micallef, R., Thasitis, I., 2019. Spatial distribution of marine macro-litter on the seafloor in the northern Mediterranean Sea: the MEDITS initiative. Sci. Mar. 83, 257-270. http://doi.org/10.3989/scimar.04987.14A.

Strafella, P., Fabi, G., Spagnolo, A., Grati, F., Polidori, P., Punzo, E., Fortibuoni, T., Marceta, B., Raicevich, S., Cvitković, I., Despalatovic, M., Scarcella, G., 2015. Spatial pattern and weight of seabed marine litter in the northern and central Adriatic Sea. Mar. Poll. Bull. 91, 120-127. http://doi.org/10.1016/j.marpolbul.2014.12.018. 
Strafella, P., Fabi, G., Despalatovic, M., Cvitković, I., Fortibuoni, T., Gomiero, A., Guicciardi, S., Marceta, B., Raicevich, S., Tassetti, A.N., Spagnolo, A., Scarcella, G., 2019. Assessment of seabed litter in the Northern and Central Adriatic Sea (Mediterranean) over six years. Mar. Poll. Bull. 141, 24-35. http://doi.org/10.1016/j.marpolbul.2018.12.054.

Tubau, X., Canals, M., Lastras, G., Rayo, X., Rivera, J., Amblas, D., 2015. Marine litter on the floor of deep submarine canyons of the Northwestern Mediterranean Sea: The role of hydrodynamic processes. Prog. Oceanogr. 134, 379-403. http://doi.org/10.1016/i.pocean.2015.03.013.

Ulses, C., Estournel, C., Puig, P., Durrieu de Madron, X., Marsaleix, P., 2008. Dense shelf water cascading in the northwestern Mediterranean during the cold winter 2005: Quantification of the export through the Gulf of Lion and the Catalan margin. Geophys. Res. Lett. 35, L07610. http://doi.org/10.1029/2008GL033257.

UNEP, 2009. Marine Litter: A Global Challenge. Nairobi: UNEP. 232 pp.

van den Beld, I.M.J., Guillaumont, B., Menot, L., Bayle, C., Arnaud-Haond, S., Bourillet, J.-F., 2017. Marine litter in submarine canyons of the Bay of Biscay. Deep-Sea Research

Part

II 145 , $142-152$. http://doi.org/10.1016/..dsr2.2016.04.013. 
Yoshikawa, T., Asoh, K., 2004. Entanglement of monofilament fishing lines 
Figure 1. Location of the mid-point of the 68 underwater video transects carried out in Cap de Creus mid and outer shelf and submarine canyon to assess the occurrence, abundance and composition of seafloor litter. Dashed lines correspond to the isobaths defining the limits of the inspected domains: northern shelf and southern shelf $(80-150 \mathrm{~m})$, canyon head $(250-400 \mathrm{~m})$, upper canyon (400-1000 m) and middle canyon (1000-1600 m). The actual path of the dives is not show on the map, but start-end positions of each dive can be found in Supplementary Table 1. Isobaths in meters.

Figure 2. Examples of litter items found in the underwater video transects carried out in Cap de Creus mid and outer continental shelf and submarine canyon. a) Broken single-use plastic bag attached to a lost trammel net on the southern continental shelf, at $110 \mathrm{~m}$ depth. b) Glass bottle found on the canyon head at $200 \mathrm{~m}$ depth. c) Piece of clothing, likely a fisherman raincoat, found on the canyon head at $305 \mathrm{~m}$ depth. d) Car tire found on the canyon head at $272 \mathrm{~m}$ depth. e) Large oil drum under a rock cliff found on the canyon head at $270 \mathrm{~m}$ depth. f) Amphorae found on the canyon head at $265 \mathrm{~m}$ depth. $g-h)$ Several long lines entangled around boulders and rocky outcrops found on the canyon head at around 250-270 m depth. i) Part of a bottom trawl net colonized by sponges, ophiuroids and holothurians, found on the continental shelf. j) Pulling cables from a bottom trawl net found on the southern continental shelf at $115 \mathrm{~m}$ depth. $\mathrm{k}-\mathrm{l})$ Trammel nets found on the southern continental shelf at 95 and $110 \mathrm{~m}$ depth, one of which was still extended and with two spiny lobsters caught in it. Green dots in the screenshots correspond 
to the laser points used to measure distances and sizes. Scale bars equal to $30 \mathrm{~cm}$ in length. Image credits: () JAGO-Team GEOMAR Kiel / ICM-CSIC.

Figure 3. Seafloor litter density for each category of urban litter (colored) and abandoned, lost or otherwise discarded fishing gears (ALDFG; grey scale) in the different domains surveyed.

Figure 4. Distribution and density of marine litter in Cap de Creus mid and outer continental shelf and submarine canyon. Litter density classes were generated following a Jenks optimization algorithm (Natural breaks). a) Urban litter items. b) Abandoned, lost or otherwise discarded fishing gears (ALDFG). Each circle corresponds to one dive. Isobaths in meters.

Figure 5. Examples of litter accumulation areas or "litter hotspots" on the submarine canyon of Cap de Creus obtained during the PROMARES cruise. a) A bottom trawl net and several ropes with living animals (Phycis blennoides, Bathynectes maravigna and Cerianthus membranaceus) at $484 \mathrm{~m}$ depth, illustrating both ALDFG occurrence and the ambiguous interactions between litter and marine organisms. Modified from Tubau et al. (2015). b) Accumulation of a variety of litter items (i.e. an old broken net, plastic bags, an aluminum can and other unidentified objects), part of which half buried, at $1200 \mathrm{~m}$ depth. Scale bars equal $30 \mathrm{~cm}$ in length.

Figure 6. Model of the average bottom current speed offshore Cap de Creus for the month of February 2012 (details in Section 2.4 and 3.3), when an 
intense event of dense-shelf water cascading was recorded (see Durrieu de Madron et al., 2013 for in-situ data collected during this period). Arrows indicate current direction. Isobaths in meters.

Figure 7. Some examples of how the bottom longlines get entangled around the main cold-water coral species that occur in Cap de Creus submarine canyon. a-d) Several colonies of Madrepora oculata filmed in vertical walls and outcropping rocks with fishing filaments entangled around them. White arrows indicate some of the points of contact with the corals. e) One of the few colonies of Lophelia pertusa observed in the canyon head with a nylon filament completely entangled around it. f) Colony of the yellow coral Dendrophyllia cornigera with a fishing line entangled around it. Image credits: (c) JAGO-Team GEOMAR Kiel / ICM-CSIC. 
Table 1. Metadata and number of litter items for each of the 68 underwater video transects examined in this study. Geographical positions correspond to approximately the middle point of each dive. Domains: NS: northern shelf $(80-150 \mathrm{~m})$; SS: southern shelf $(80-150 \mathrm{~m})$; $\mathrm{CH}$ : canyon head (150-400m); UC: upper canyon (400-1000m); MC: middle canyon (1000-1600m). ALDFG: abandoned, lost or otherwise discarded fishing gear.

\begin{tabular}{|c|c|c|c|c|c|c|c|c|c|}
\hline \multirow[b]{2}{*}{ Dive } & \multirow{2}{*}{$\begin{array}{c}\text { Date } \\
\text { (dd/mm/yy) }\end{array}$} & \multicolumn{2}{|c|}{ Position } & \multicolumn{3}{|c|}{ Depth } & \multirow{2}{*}{$\begin{array}{l}\text { Analyzed } \\
\text { area }\left(m^{2}\right)\end{array}$} & \multirow{2}{*}{$\begin{array}{l}\text { Urban items } \\
\text { (n) }\end{array}$} & \multirow{2}{*}{$\begin{array}{c}\text { ALDFG } \\
\text { (n) }\end{array}$} \\
\hline & & Lat. $\mathbf{N}$ & Long. E & Vehicle & range (m) & Domain & & & \\
\hline 1 & 09/09/07 & 42.3896 & 3.3142 & JAGO & $215-186$ & $\mathrm{CH}$ & 144 & & 18 \\
\hline 2 & 09/09/07 & 42.3497 & 3.3585 & JAGO & $386-377$ & $\mathrm{CH}$ & 406 & & 11 \\
\hline 3 & $10 / 09 / 07$ & 42.3882 & 3.3159 & JAGO & $199-173$ & $\mathrm{CH}$ & 1108 & & 45 \\
\hline 4 & $12 / 09 / 07$ & 42.3869 & 3.3209 & JAGO & $302-302$ & $\mathrm{CH}$ & 196 & & 8 \\
\hline 5 & $13 / 09 / 07$ & 42.3784 & 3.3283 & JAGO & $316-302$ & $\mathrm{CH}$ & 516 & 3 & 18 \\
\hline 6 & $13 / 09 / 07$ & 42.3955 & 3.3033 & JAGO & $168-153$ & $\mathrm{CH}$ & 324 & & \\
\hline 7 & $14 / 09 / 07$ & 42.3575 & 3.3358 & JAGO & $234-236$ & $\mathrm{CH}$ & 944 & 4 & 31 \\
\hline 8 & $15 / 09 / 07$ & 42.3704 & 3.3376 & JAGO & $293-264$ & $\mathrm{CH}$ & 376 & 6 & 34 \\
\hline 9 & $15 / 09 / 07$ & 42.3919 & 3.3129 & JAGO & $282-165$ & $\mathrm{CH}$ & 970 & 1 & 119 \\
\hline 10 & 25/08/09 & 42.3702 & 3.2988 & Bleeper EVO & $109-110$ & NS & 452 & 1 & 1 \\
\hline 11 & $26 / 08 / 09$ & 42.3471 & 3.3093 & Bleeper EVO & $115-112$ & NS & 41.5 & & \\
\hline 12 & $26 / 08 / 09$ & 42.3397 & 3.3167 & Bleeper EVO & $98-95$ & NS & 279.5 & & \\
\hline 13 & $26 / 08 / 09$ & 42.3691 & 3.2606 & Bleeper EVO & $99-99$ & NS & 507.5 & & 1 \\
\hline 14 & $27 / 08 / 09$ & 42.3924 & 3.2569 & Bleeper EVO & $97-99$ & NS & 338 & & \\
\hline 15 & $27 / 08 / 09$ & 42.3839 & 3.2719 & Bleeper EVO & $102-103$ & NS & 238 & & \\
\hline 16 & 27/08/09 & 42.3929 & 3.2882 & Bleeper EVO & $107-107$ & NS & 86.5 & & \\
\hline 17 & 27/08/09 & 42.3900 & 3.2924 & Bleeper EVO & $106-107$ & NS & 219 & & \\
\hline 18 & $27 / 08 / 09$ & 42.3404 & 3.3354 & Bleeper EVO & $111-117$ & NS & 218 & & 1 \\
\hline 19 & $23 / 09 / 09$ & 42.3795 & 3.2690 & Nemo ROV & $102-101$ & NS & 662 & 1 & \\
\hline 20 & $23 / 09 / 09$ & 42.3862 & 3.3044 & Nemo ROV & $111-111$ & NS & 252 & & \\
\hline 21 & $23 / 09 / 09$ & 42.3569 & 3.3269 & Nemo ROV & $151-118$ & NS & 218 & & \\
\hline 22 & $24 / 09 / 09$ & 42.3632 & 3.2977 & Nemo ROV & $111-108$ & NS & 146 & & 2 \\
\hline 23 & $26 / 09 / 09$ & 42.3945 & 3.3035 & Nemo ROV & $148-142$ & NS & 41.5 & & \\
\hline 24 & 27/09/09 & 42.3636 & 3.3303 & Nemo ROV & $166-160$ & $\mathrm{CH}$ & 203 & & 5 \\
\hline 25 & $27 / 09 / 09$ & 42.3667 & 3.3185 & Nemo ROV & $121-115$ & NS & 312.5 & & \\
\hline 26 & $27 / 09 / 09$ & 42.3443 & 3.3081 & Nemo ROV & $111-94$ & NS & 284.5 & 3 & 3 \\
\hline 27 & $28 / 09 / 09$ & 42.3317 & 3.3623 & Nemo ROV & $130-148$ & SS & 118.5 & & \\
\hline 28 & $28 / 09 / 09$ & 42.3833 & 3.2646 & Nemo ROV & $100-99$ & NS & 234.5 & & \\
\hline 29 & $28 / 09 / 09$ & 42.3852 & 3.2696 & Nemo ROV & $102-101$ & NS & 203 & & \\
\hline 30 & $29 / 09 / 09$ & 42.3310 & 3.3706 & Nemo ROV & $160-150$ & $\mathrm{CH}$ & 43 & & \\
\hline 31 & 29/09/09 & 42.3851 & 3.4001 & Nemo ROV & $137-137$ & NS & 45 & & \\
\hline 32 & $13 / 06 / 10$ & 42.3085 & 3.3965 & JAGO & $116-117$ & SS & 1868 & & 18 \\
\hline 33 & $13 / 06 / 10$ & 42.3096 & 3.4368 & JAGO & $132-128$ & SS & 1188 & & 5 \\
\hline 34 & $14 / 06 / 10$ & 42.2635 & 3.3403 & JAGO & $94-94$ & SS & 1320 & & \\
\hline 35 & $17 / 06 / 10$ & 42.2852 & 3.4608 & JAGO & $127-125$ & SS & 1872 & & 4 \\
\hline 36 & $18 / 06 / 10$ & 42.3078 & 3.3624 & JAGO & $108-114$ & SS & 1728 & 4 & 23 \\
\hline 37 & $03 / 07 / 11$ & 42.3315 & 3.4656 & Liropus 2000 & $156-790$ & $\mathrm{CH} / \mathrm{UC}$ & 15525 & 34 & 10 \\
\hline 38 & 04/07/11 & 42.3470 & 3.4631 & Liropus 2000 & 681-795 & UC & 9923.4 & 60 & \\
\hline 39 & $05 / 07 / 11$ & 42.2227 & 3.8298 & Liropus 2000 & $1491-1570$ & $\mathrm{MC}$ & 6456.3 & 69 & \\
\hline 40 & $05 / 07 / 11$ & 42.2847 & 3.6399 & Liropus 2000 & 1198-1245 & $\mathrm{MC}$ & 5789.1 & 161 & 5 \\
\hline 41 & $06 / 07 / 11$ & 42.3562 & 3.3361 & Liropus 2000 & $248-299$ & $\mathrm{CH}$ & 863.1 & 2 & \\
\hline 42 & $06 / 07 / 11$ & 42.3782 & 3.3332 & Liropus 2000 & $270-371$ & $\mathrm{CH}$ & 1375.8 & 3 & 19 \\
\hline 43 & $06 / 07 / 11$ & 42.3888 & 3.3709 & Liropus 2000 & $176-321$ & $\mathrm{CH}$ & 1998.3 & 9 & 7 \\
\hline 44 & $07 / 07 / 11$ & 42.3771 & 3.3541 & Liropus 2000 & $387-522$ & UC & 8814 & 28 & 5 \\
\hline 45 & 06/07/12 & 42.2712 & 3.4109 & Nemo ROV & $126-126$ & SS & 252.5 & & \\
\hline 46 & $06 / 07 / 12$ & 42.2946 & 3.4236 & Nemo ROV & $127-126$ & SS & 174 & & 1 \\
\hline 47 & $06 / 07 / 12$ & 42.3070 & 3.4454 & Nemo ROV & $147-129$ & SS & 373.5 & & 8 \\
\hline 48 & $07 / 07 / 12$ & 42.3393 & 3.3505 & Nemo ROV & $128-125$ & NS & 415 & 1 & 1 \\
\hline 49 & $07 / 07 / 12$ & 42.3366 & 3.3272 & Nemo ROV & $99-96$ & NS & 173 & 1 & 5 \\
\hline 50 & $07 / 07 / 12$ & 42.3452 & 3.3226 & Nemo ROV & $108-109$ & NS & 202.5 & & 1 \\
\hline 51 & $07 / 07 / 12$ & 42.3435 & 3.2948 & Nemo ROV & $90-88$ & NS & 89 & & 2 \\
\hline 52 & 07/07/12 & 42.3412 & 3.3360 & Nemo ROV & $115-116$ & NS & 89 & & \\
\hline 53 & $08 / 07 / 12$ & 42.3344 & 3.3249 & Nemo ROV & $98-91$ & NS & 381.5 & & 8 \\
\hline 54 & $08 / 07 / 12$ & 42.3572 & 3.2770 & Nemo ROV & $103-97$ & NS & 432.5 & & 1 \\
\hline 55 & $08 / 07 / 12$ & 42.3698 & 3.2832 & Nemo ROV & $109-105$ & NS & 287 & & \\
\hline 56 & $09 / 07 / 12$ & 42.3967 & 3.2840 & Nemo ROV & $108-104$ & NS & 279 & & \\
\hline 57 & $09 / 07 / 12$ & 42.3219 & 3.3678 & Nemo ROV & $127-123$ & SS & 436 & & 1 \\
\hline 58 & $09 / 07 / 12$ & 42.3463 & 3.3184 & Nemo ROV & $107-102$ & NS & 474.5 & 2 & 9 \\
\hline 59 & $09 / 07 / 12$ & 42.3514 & 3.2897 & Nemo ROV & $96-98$ & NS & 142 & & 1 \\
\hline 60 & $09 / 07 / 12$ & 42.3808 & 3.3177 & Nemo ROV & $210-115$ & $\mathrm{CH} / \mathrm{NS}$ & 544.5 & & \\
\hline 61 & $09 / 07 / 12$ & 42.4115 & 3.2536 & Nemo ROV & $98-98$ & NS & 139.5 & & \\
\hline 62 & $09 / 07 / 12$ & 42.3056 & 3.4305 & Nemo ROV & $124-129$ & SS & 395.5 & & 5 \\
\hline 63 & $10 / 07 / 12$ & 42.3004 & 3.3671 & Nemo ROV & $116-118$ & SS & 92 & & 3 \\
\hline 64 & $10 / 07 / 12$ & 42.3021 & 3.3567 & Nemo ROV & $101-96$ & SS & 287.5 & & \\
\hline 65 & $27 / 01 / 13$ & 42.2989 & 3.3492 & Bleeper EVO & $90-96$ & SS & 319.5 & & \\
\hline 66 & $06 / 06 / 13$ & 42.2824 & 3.3394 & Bleeper EVO & $90-92$ & SS & 300.5 & & \\
\hline 67 & $14 / 10 / 13$ & 42.2726 & 3.3080 & Bleeper EVO & $83-79$ & SS & 163.5 & & \\
\hline 68 & $04 / 12 / 13$ & 42.2677 & 3.3780 & Bleeper EVO & $121-121$ & SS & 445.5 & 1 & \\
\hline
\end{tabular}


Table 2. Number of cold-water coral colonies and per species percentage of entanglement with longlines as observed in the 8 canyon head dives evaluated for this study where cold-water corals were present. All dives were performed at depths between 215 and $390 \mathrm{~m}$. Longline density expressed both as items per ha and items per 100 linear meters.

\begin{tabular}{|c|c|c|c|c|c|c|c|c|c|}
\hline \multirow[b]{2}{*}{ Dive } & \multirow{2}{*}{$\begin{array}{l}\text { Depth } \\
\text { (m) }\end{array}$} & \multicolumn{2}{|c|}{ Longline dens. } & \multicolumn{2}{|c|}{ M. oculata } & \multicolumn{2}{|r|}{ L. pertusa } & \multicolumn{2}{|c|}{ D. cornigera } \\
\hline & & lines $h a^{-1}$ & lines $100 \mathrm{~m}$ & $\mathbf{n}$ & $\%$ entangled & $\mathbf{n}$ & $\%$ entangled & $\mathbf{n}$ & $\%$ entangled \\
\hline 1 & $215-186$ & 1250 & 25 & 43 & 9.3 & & & & \\
\hline 2 & $386-377$ & 270.9 & 5.4 & 7 & 0 & 3 & 0 & & \\
\hline 3 & $199-173$ & 406.1 & 8.1 & 58 & 6.9 & 2 & 50 & 15 & 0 \\
\hline 4 & $302-302$ & 408.2 & 8.2 & 4 & 0 & 1 & 0 & & \\
\hline 5 & $316-302$ & 348.8 & 7 & 37 & 2.7 & & & 1 & 0 \\
\hline 7 & $234-236$ & 328.4 & 6.6 & 5 & 0 & & & 1 & 0 \\
\hline 8 & $293-264$ & 904.3 & 18.1 & 3 & 33.3 & 1 & 100 & 6 & 16.7 \\
\hline 9 & $282-165$ & 1226.8 & 24.5 & 145 & 15.2 & & & 3 & 66.7 \\
\hline
\end{tabular}




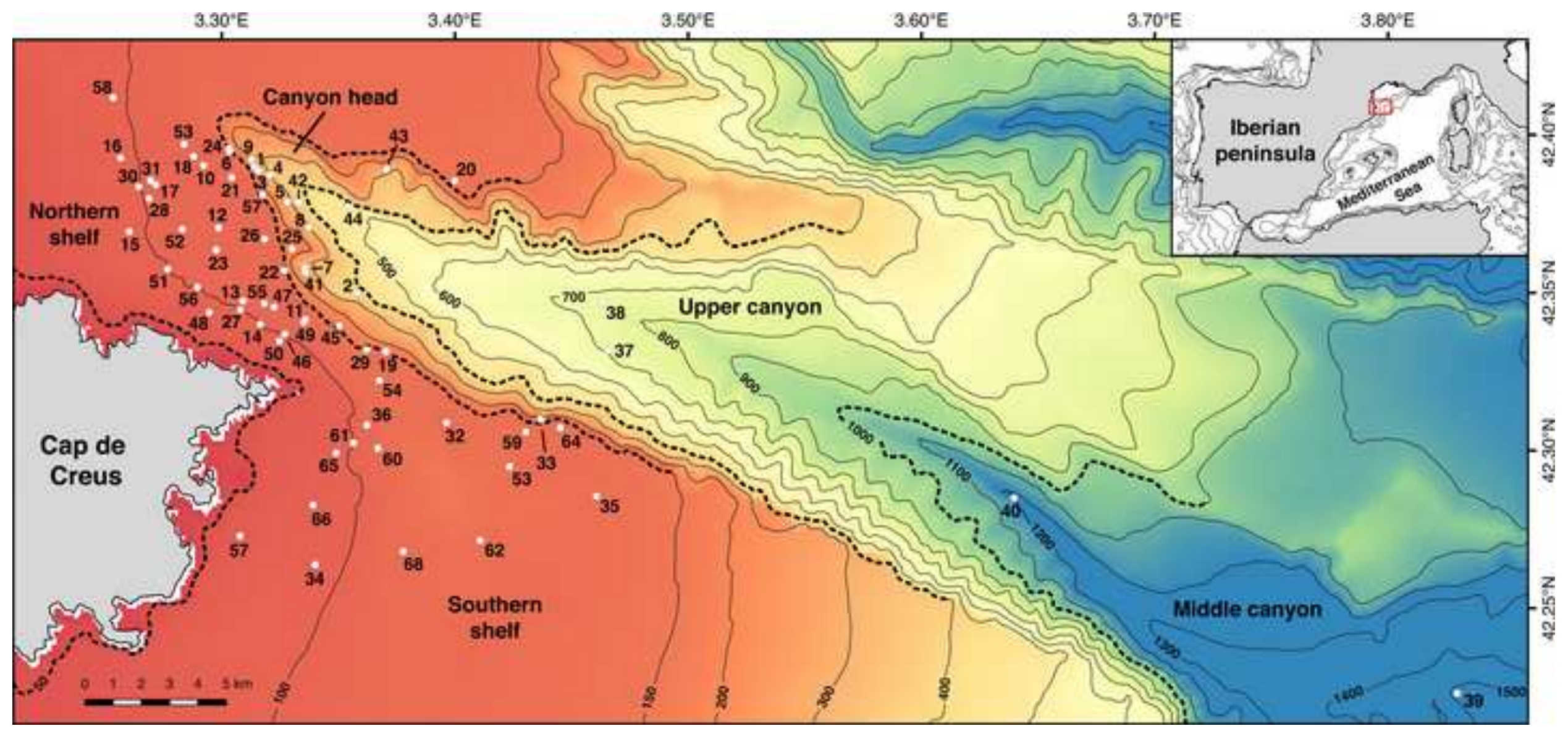


Figure 2 - 2-column fitting
Click here to download high resolution image
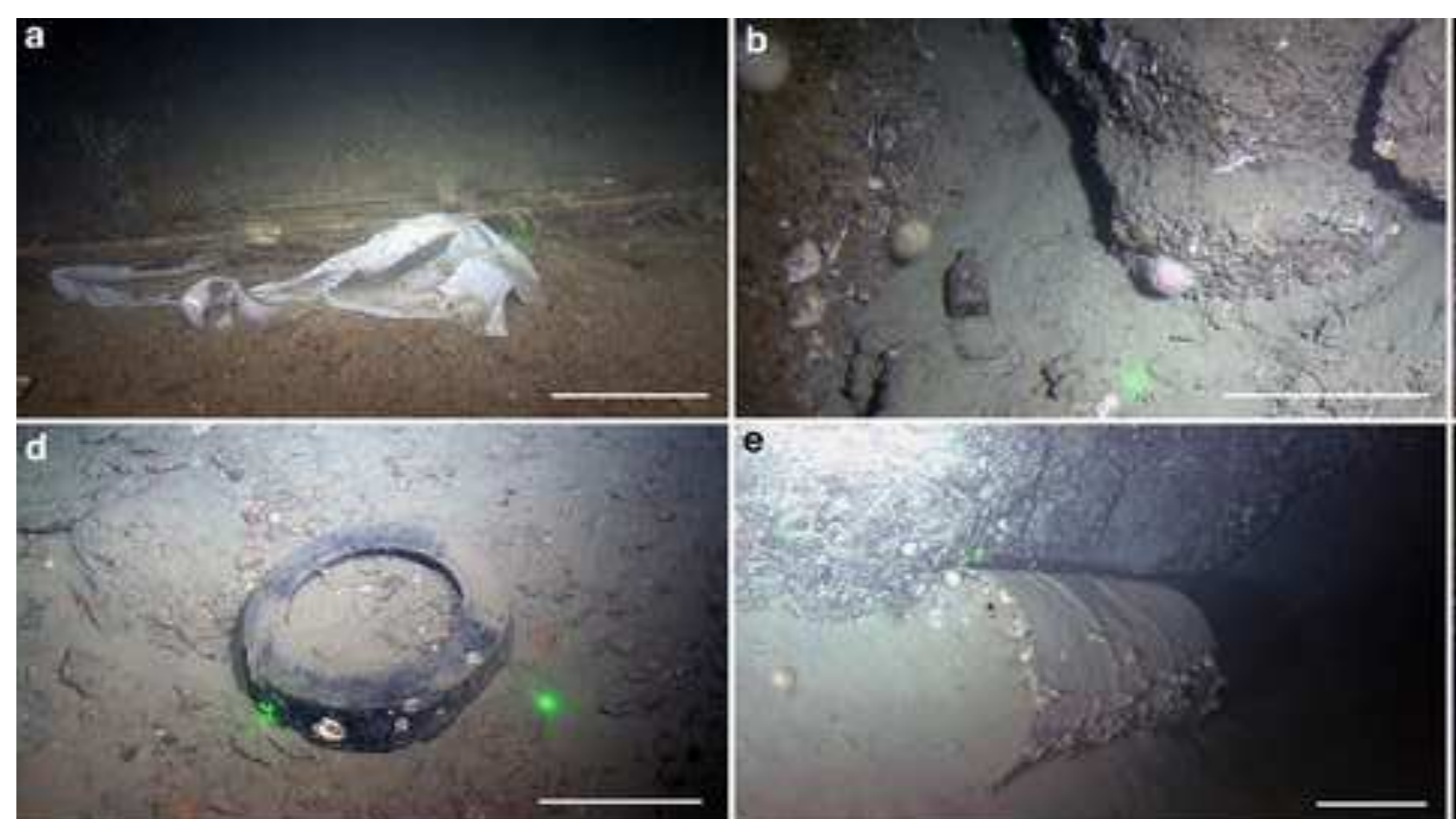

C
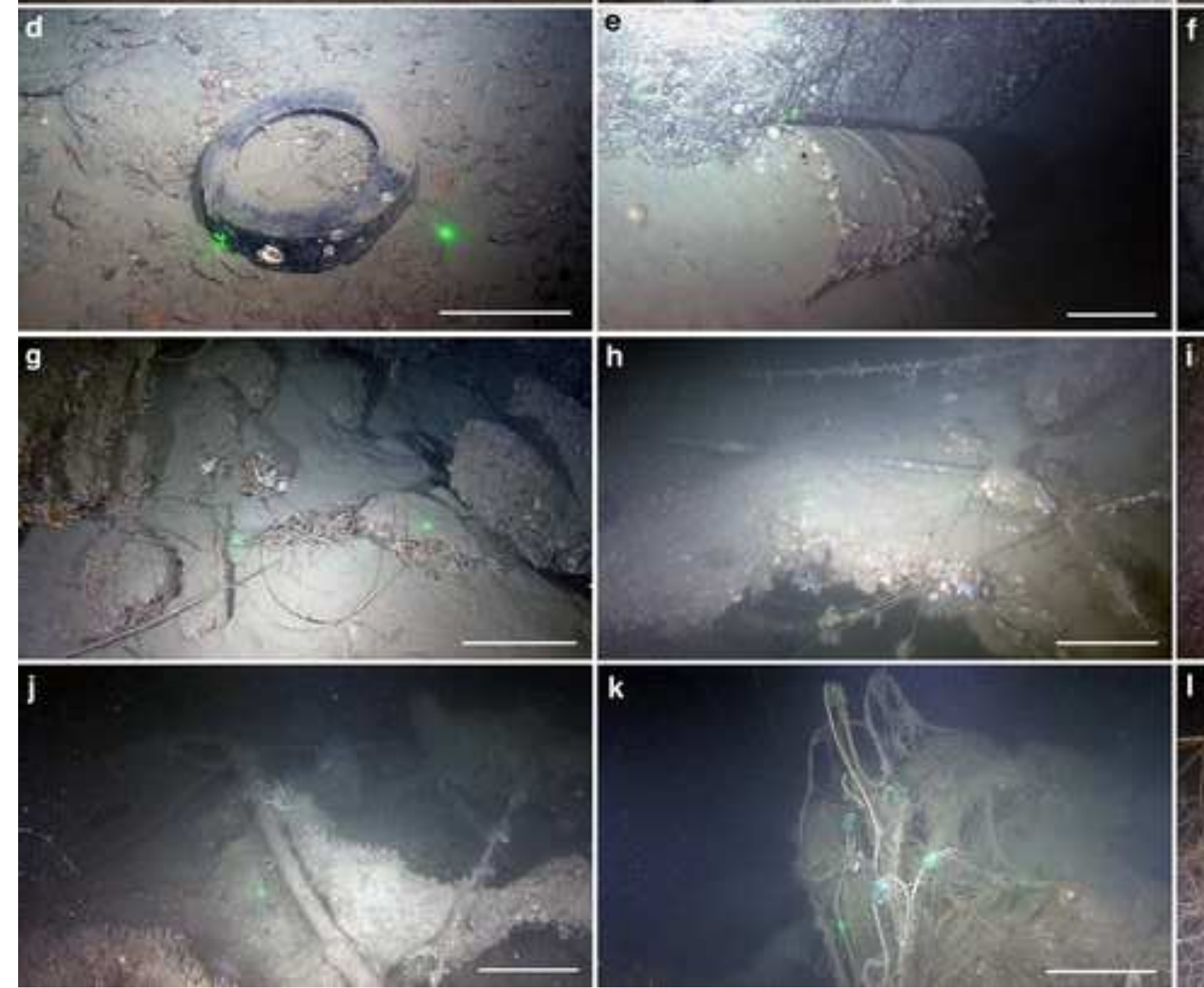

h
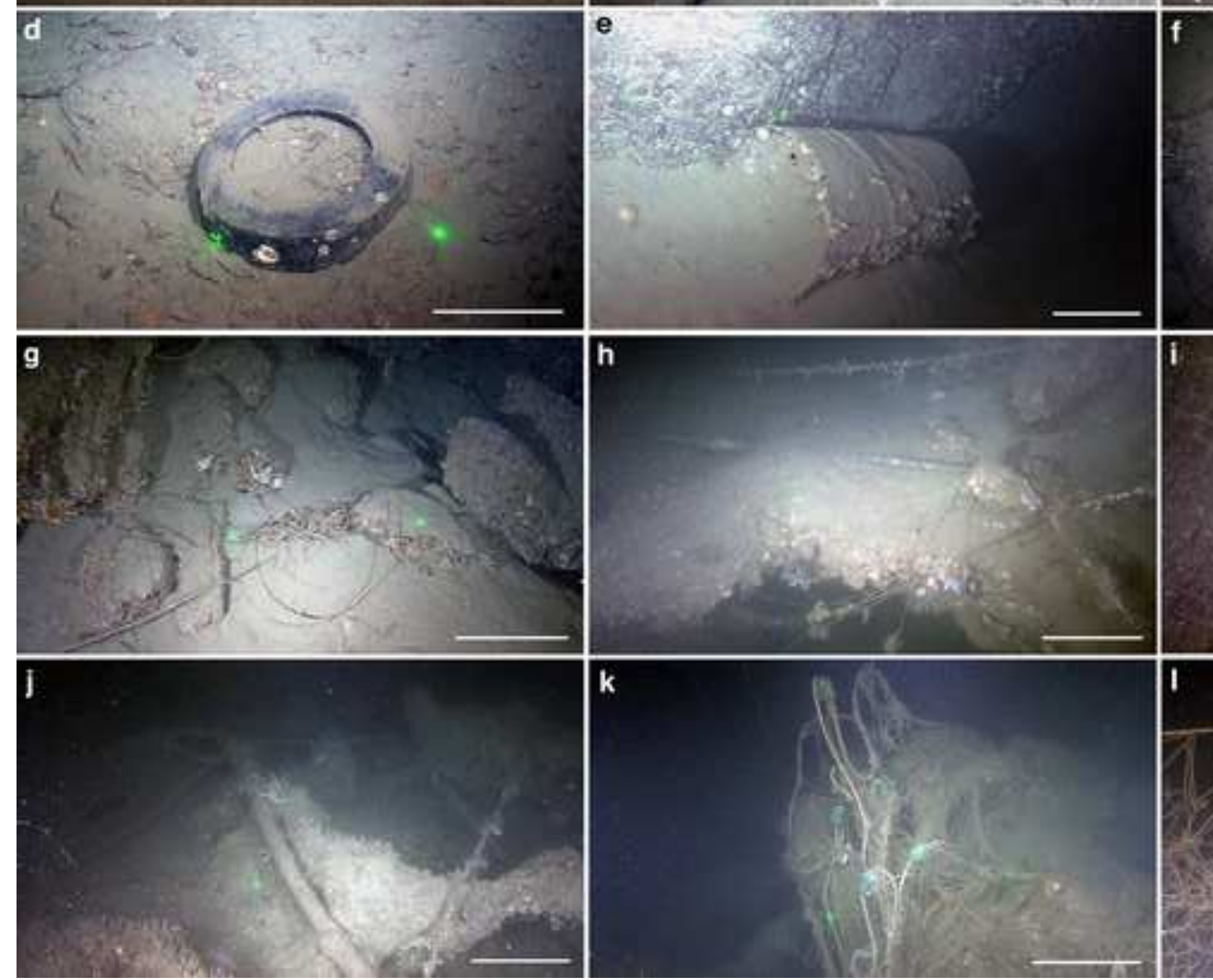

.
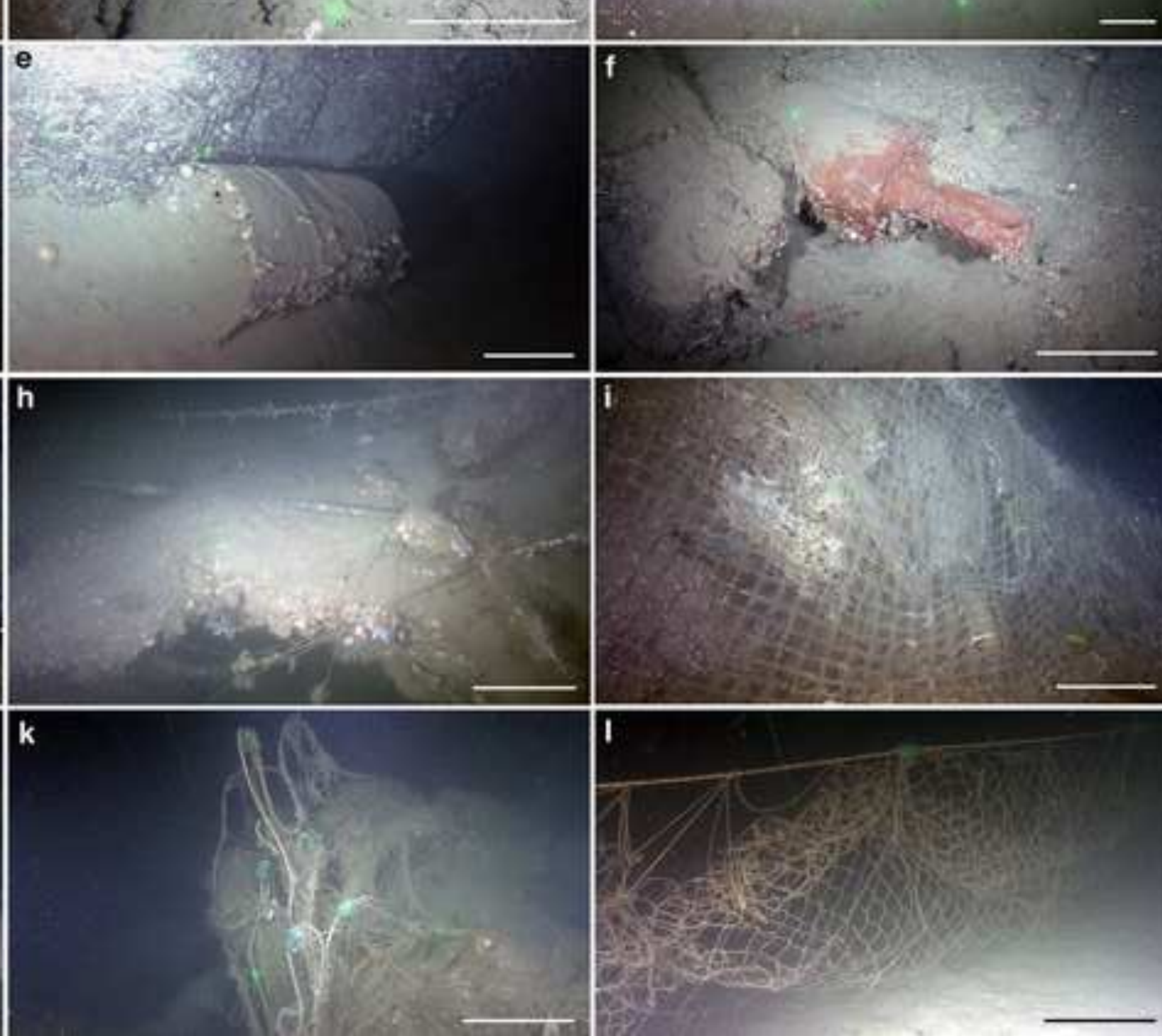

I

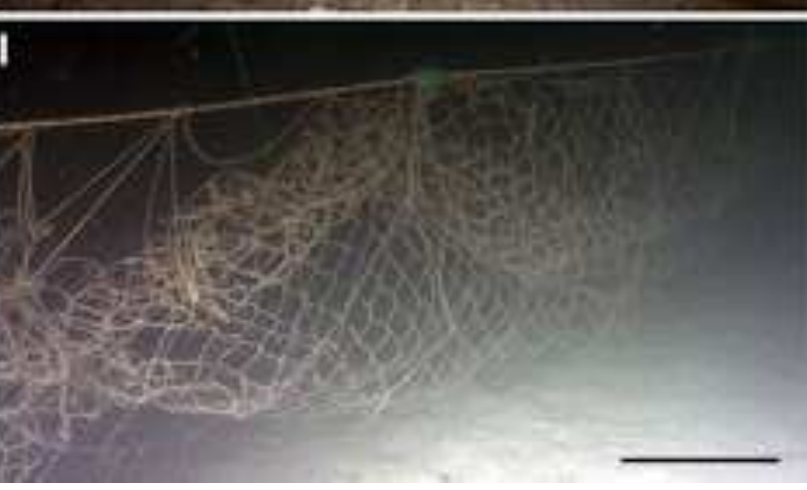


Click here to download high resolution image

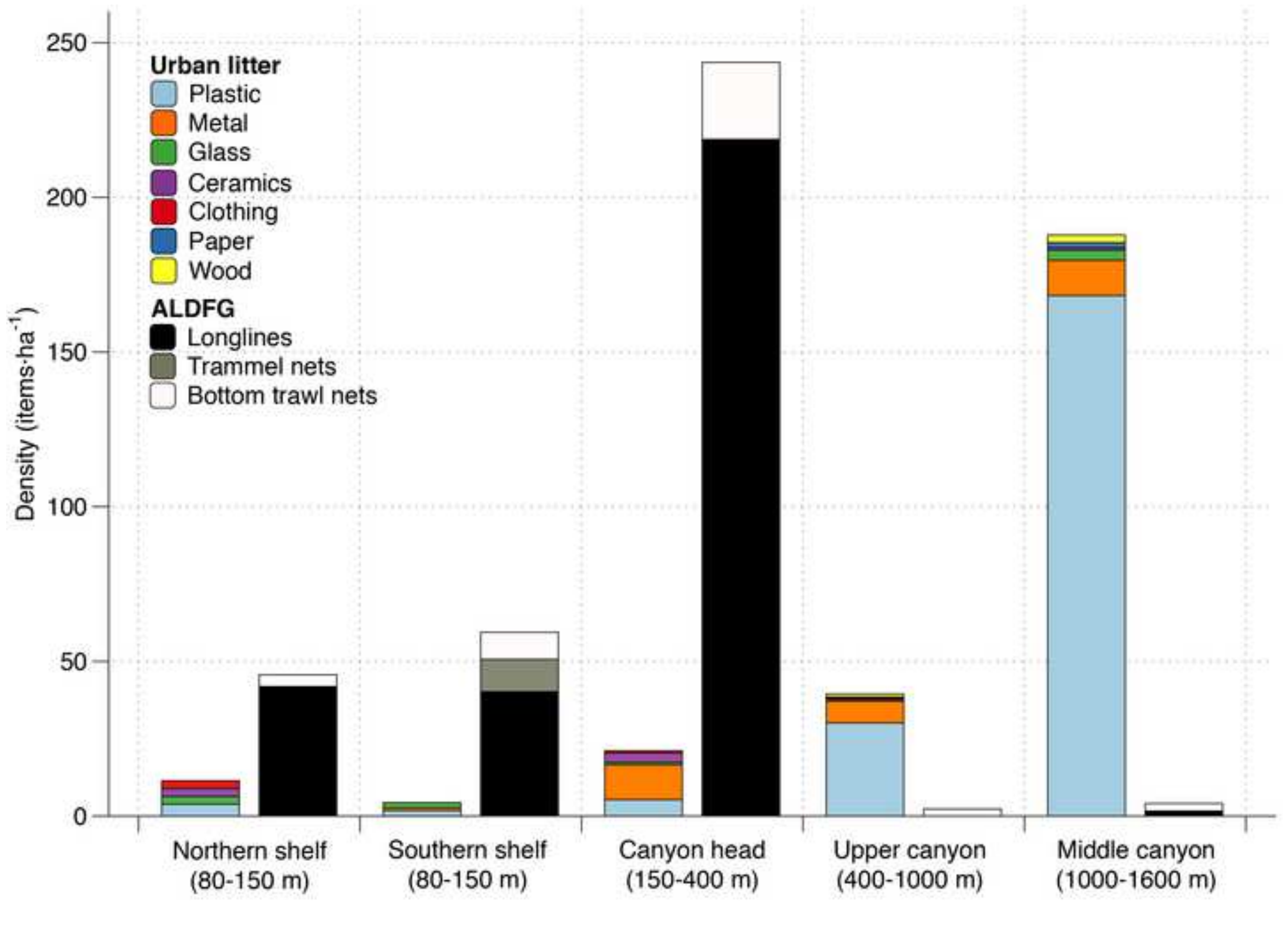

(80-150 m)

(80-150 m)

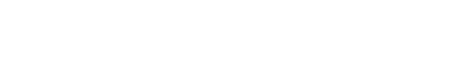




\section{Figure 4 -2-column fitting}

Click here to download high resolution image

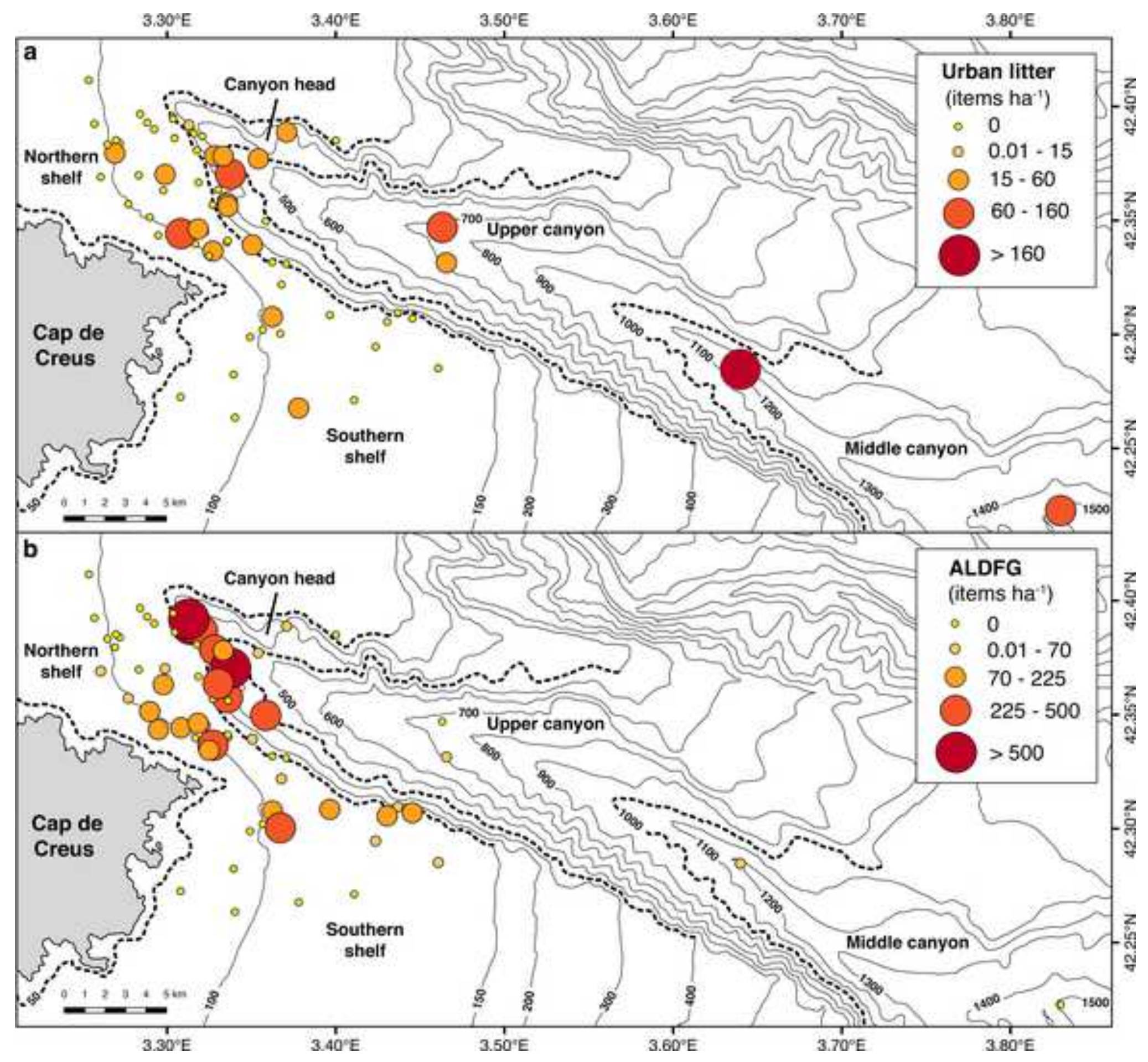


Figure 5 - 2-column fitting
Click here to download high resolution image

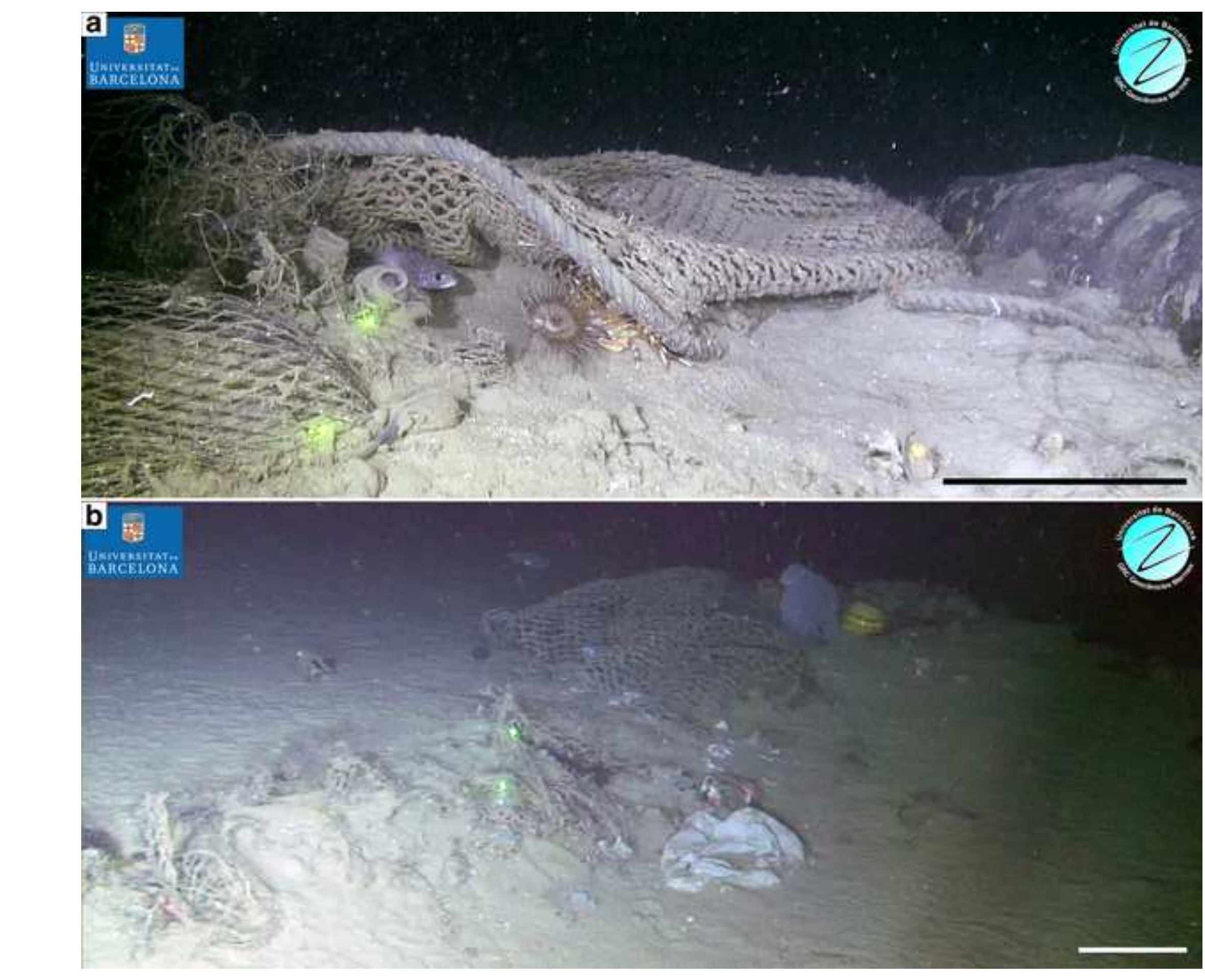

b :

Hestecion

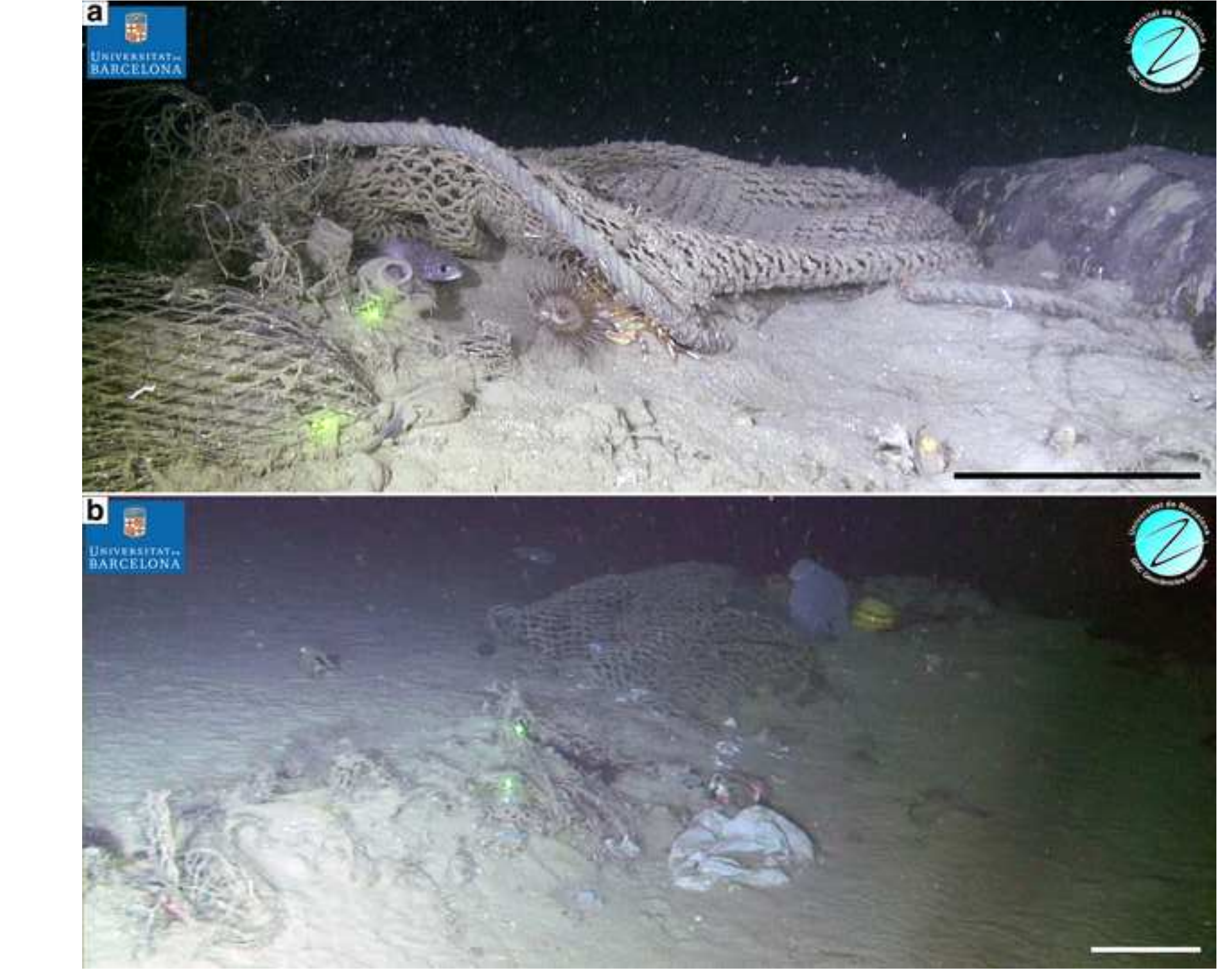




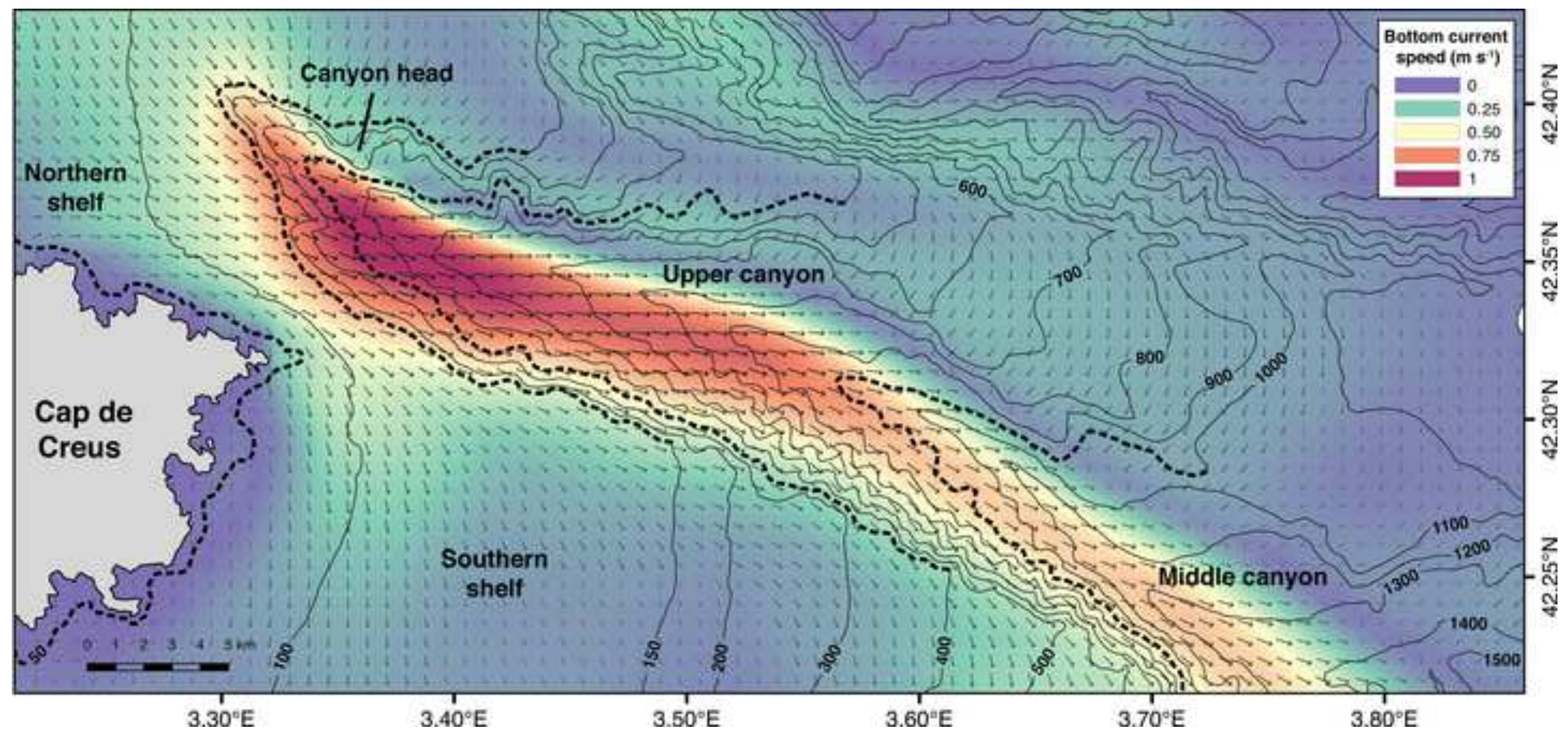


Figure 7 - 2-column fitting

Click here to download high resolution image
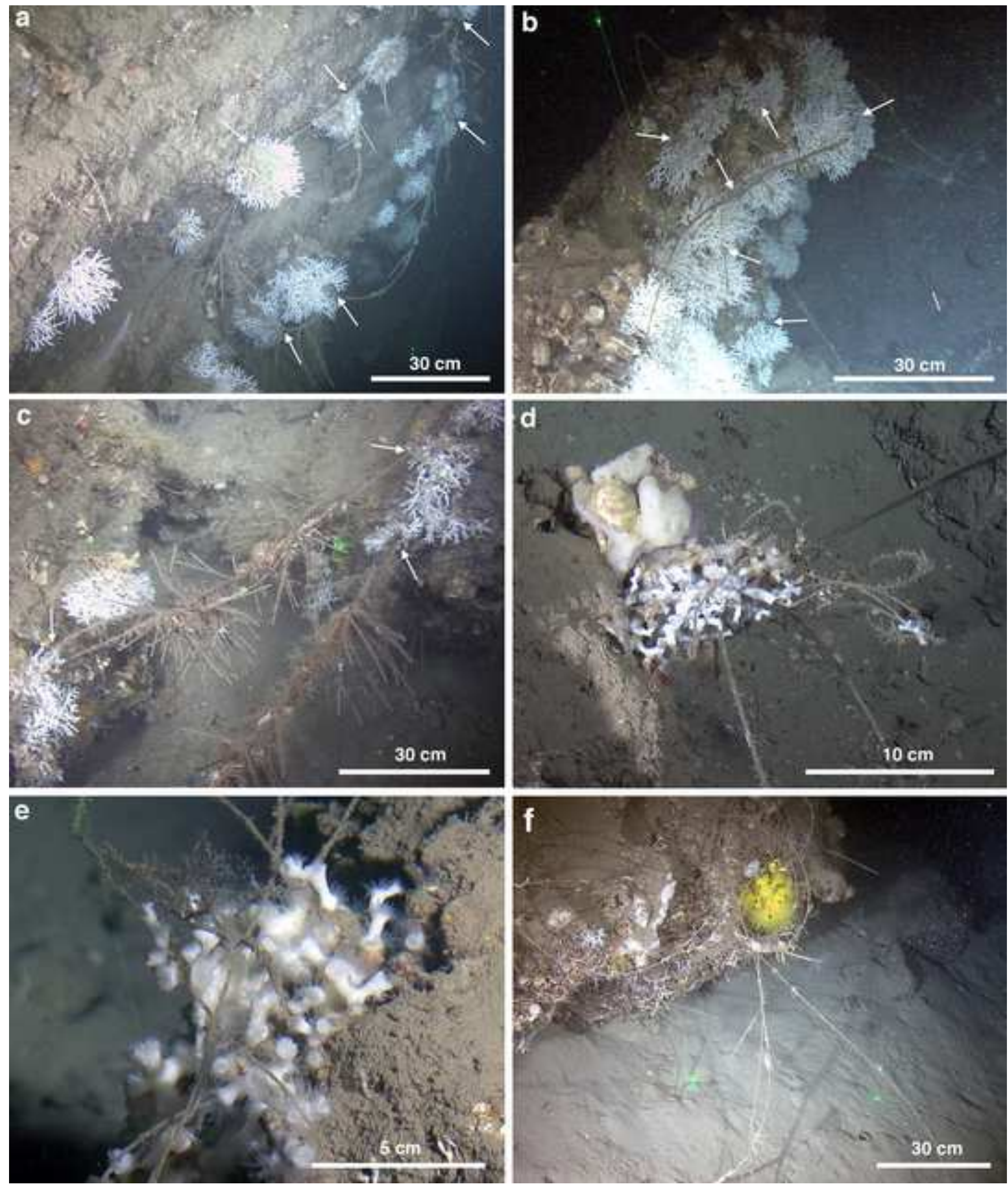
Click here to download Supplementary Data: Supplementary table 1.docx

Supplementary Table 1
Click here to download $\mathrm{S}$ Click here to download Supplementary Data: Supplementary table 1.docx

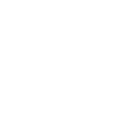

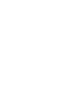

(1)

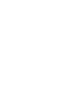
(1) (1) (1) (1)

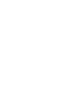

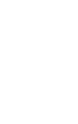
(1) . . . . . . . . . . . . . . . . .

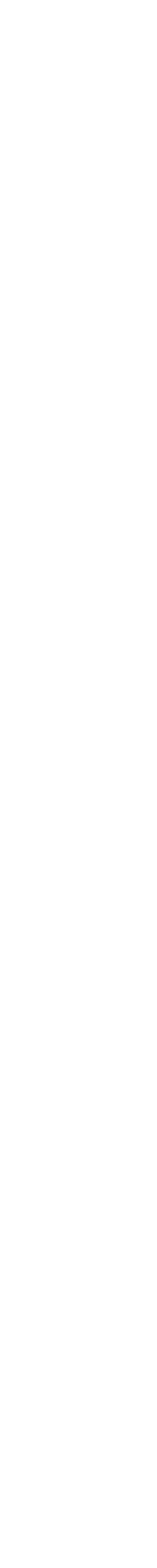

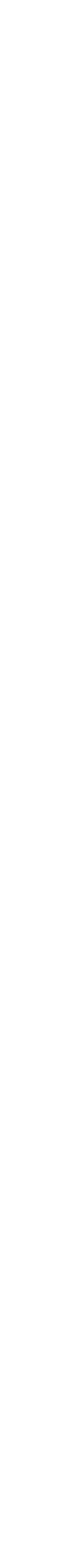
(1)

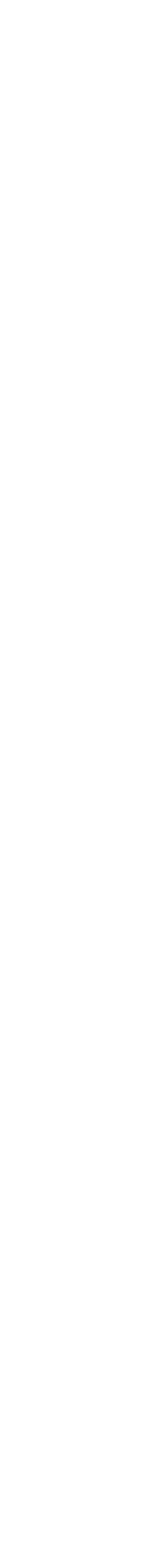




\section{Declaration of interests}

\The authors declare that they have no known competing financial interests or personal relationships that could have appeared to influence the work reported in this paper.

$\square$ The authors declare the following financial interests/personal relationships which may be considered as potential competing interests:

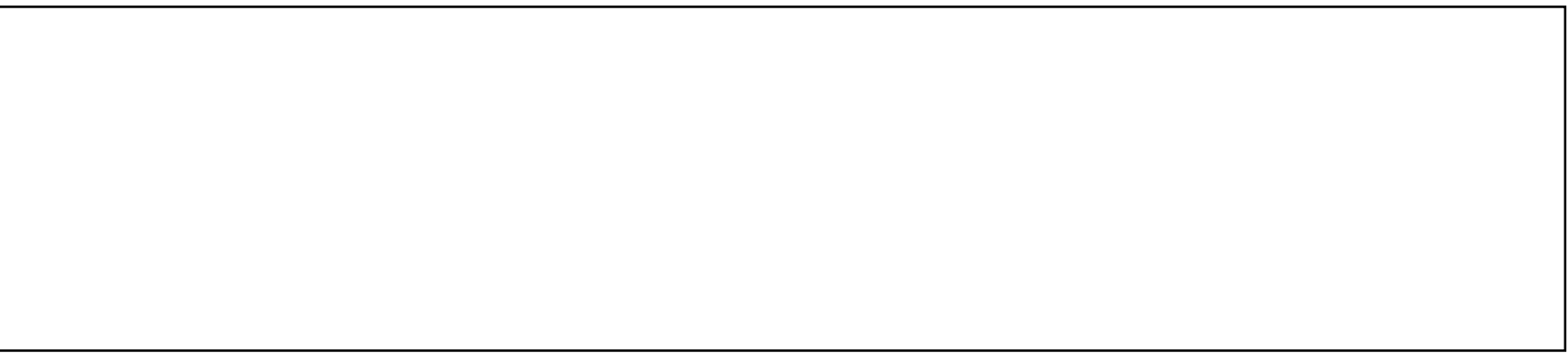




\section{CRediT author statement}

Carlos Dominguez-Carrió: Conceptualization, Investigation, Data Curation, Formal analysis, Visualization, Writing - Original draft. Anna Sanchez-Vidal: Conceptualization, Data Curation, Writing - Reviewing \& Editing. Claude Estournel: Methodology, Writing - Reviewing \& Editing. Guillem Corbera: Data Curation, Writing - Reviewing \& Editing. Joan Lluís Riera: Supervision, Writing - Reviewing \& Editing. Covadonga Orejas: Funding acquisition, Project administration, Investigation, Writing - Reviewing \& Editing. Miquel Canals: Funding acquisition, Project administration, Writing - Reviewing \& Editing. Josep-Maria Gili: Funding acquisition, Project administration, Supervision, Writing - Reviewing \& Editing. 